\title{
THE FORMATION OF PPME'S RELIGIOUS IDENTITY
}

\section{Sujadi}

Leiden University, the Netherlands

\section{Abstract}

The Persatuan Pemuda Muslim se-Eropa (PPME, Young Muslim Association in Europe) with its diverse religious backgrounds was established by many Indonesians living in the Netherlands. The organisation takes consideration not only the development of religious practices in Indonesia, but also the prevailing condition in the Netherlands in dealing its religious identity formation. The article focuses on how the organisation's religious identitiy has been shaped. To deal with this issue, a historical approach is used, combining chronological presentation with analytical approach. This approach is in line with the objective of this research, i.e. to see the ways in which the PPME's religious identity take shape through reading the bulletins and religious practices. Because of its residence in the Netherlands, the shaping of its religious identity has been dictated by neither political force nor agenda. This led to in acceptance of diverse and plural ideas within the organisation. This has entailed the occurrence of diverse religious identities. Adjustments to the Dutch contexts have been featured by PPME. As a consequence, memories of Indonesia have been adapted to the atmosphere of the Netherlands.

Persatuan Pemuda Muslim se-Eropa (PPME) dengan keragaman latar belakang orientasi keagamaan anggotanya adalah organisasi yang didirikan oleh orang-orang Islam Indonesia yang tinggal di Belanda. PPME memperbatikan tidak saja keberagamaan ala Indonesia, namun juga kondisi di Belanda, utamanya dalam menegaskan identitas keberagamaan mereka. Artikel ini menjelaskan bagaimana identitas keagamaan PPME tersebut 
dibentuk. Untuk. mendiskusikan tema tersebut, digunakan pendekatan sejarah --pendekatan yang tidak hanya menyajikan hasil penelitian secara kronologis tetapijuga eksplanasi analitis. Pendekatan ini sejalan dengan tujuan penulisan artikel ini, yaitu mengidentifikasi metode pembentukan identitas keagamaan PPME. Hal ini dilakukan dengan mencermati bulletin yang diterbitkan PPME dan aktifitas keagamaan yang dilaksanakan. Karena bidup di Belanda, identitas keberagamaan PPME berjalan dengan alamiah, tanpa intervensi politik. Ini mengakibatkan pada penerimaan PPME terbadap keragaman cara pandang yang hidup dalam PPME. Yang terakhir, PPME berusaha keras untuk. menyesuaikan identitas keberagamaan mereka dengan konteks Belanda. Konsekuensinya, memori tentang Indonesia itu akbirnya diadaptasi dengan situasi dan kondisi di Belanda.]

Keywords: identity formation, religious practices, PPME

DOI: $10.14421 /$ ajis.2013.511.81-128

\section{A. Introduction}

The foundation of the Persatuan Pemuda Muslim se-Eropa (PPME, Young Muslim Association in Europe), ${ }^{1}$ i.e., combining European and

${ }^{1}$ On April 11, 1971, a gathering was held commenced at 12 p.m. and attended by twenty one participants, resulting in an agreement to pick up a name for the new organization, i.e. Persatuan Pemuda Muslim se-Eropa (PPME, Young Muslim Association in Europe). There were, in fact, other choices put forward such as Gerakan Pemuda Islam Eropa (Islamic Youth Movement in Europe), and Organisasi Pemuda Islam Eropa (Islamic Youth Organization in Europe). Two arguments for the chosen name. Firstly, the first word "Persatuan" (Unity) fulfilled to their needs at the moment. Besides, the choice, especially related to the word "Eropa" (Europe), accommodated not only a Dutch founder, Rachmat Zitter whose house was frequently used for the gatherings of Indonesian youths, but also another founder's nationality, i.e., Amir al-Hajri holding the passport of the Republic of South Yaman. This historical gathering ended with their declaration of its establishment. The following is their declaration:

"In the Name of Allah, the Most Gracious and the Most Merciful

Declaration

We, attending this gathering which is held at present and in this place, declare the establishment of this organization called Young Muslim Association in Europe".

Barenstraat 4, The Hague [a capital city of administrative affairs of the Netherlands], 12/4-71. 
Indonesian charateristics ${ }^{2}$ with various members having differing Islamic and ethnic backgrounds, became the guide for the organisation. As a consequence, this base, along with the characteristics, has also served as compass of its religious identity formation. The condition faced by Muslims in the Netherlands and Islam in Indonesia have been taken into account by the PPME's board in dealing with religious activities. Thus, even though Islamic practices in Indonesia remain influential on PPME's religious activities, ${ }^{3}$ there have somehow been adjustments, and has, generally, been no political force in its religious identity formation.

The present article deals with the formation of PPPME's religious identities. This subject is discussed in two topics; 1) through religious practices and 2) through the writings available in al-Ittibaad (1985) and Euromoslem (1992). These two are fundamental sources which play significant roles in shaping the religious identity of Indonesian-Muslims in the Netherlands.

\section{B. Through Religious Practices}

The following part discusses religious practices and rituals among Indonesian Muslims in the Netherlands (PPME's members and

The twenty founders were M. Sayuti Suhaib, Abdul Wahid Kadungga, Imam, Ozir M. Isa, Rusli Bena, A. Hambali Maksum, Ujang HS, Azmihardi S., T. Razali, Husni Basuni, Ali Khalik, S. Abidin, I. Idram, M. Rais Mustafa, A. Muiz, Suwardi, Abdurrahman Wahid, Moh. Syukur, Machfud Muchtar (Yus), M. Amir al-Hajri, and. Ade Baharuddin. In addition to the twenty one people in the meeting, there existed two important figures, who could not take part in it. One of them was Chaeron. He was an active and creative figure in this new organization. He was both a founder and a member of the commission for the statute and bylaws, and the creator of the logo employed for the organization. He was absent in the meeting due to his job that brought him to Groningen. Another important person was the owner of Indonesian youth's headquarters, and a member of the board who was in charge of welfare affairs in the new organization, namely, Rachmat Zitter, who went to Brussel. The elected chair person of the new Muslim organization was Kadungga, a son in law of Kahar Muzakar, a former key figure of the Darul Islam (Islamic Country) movement in South Celebes.

${ }^{2}$ Cf.: Article 4, Bijvoegsel van de Nederlandse Staatscourant van 14 Agustus 1974 156, 1, and cf.: Uittreksel uit het Verenigingenregister van de Kamer van Koophandel en Fabrieken voor's-Gravenhage, V 410668, Desember 13,1994, p.1.

3 Cf.: Ahmet Yukleyen, "Localizing Islam in Europe: Religious Activism among Turkish Islamic Organizations in the Netherlands", in Muslim Minority Affairs 3, Vol. 29, September 2009, p. 294. 
sympathizers) which are significant in the formation of their religious identity. This discussion includes religious education, ikhtilat, marriages, religious outreaches for converts, religious lessons for youth, Dutchconverts, and Dauroh. In this way, the religious and socio-culutral backgrounds of PPME's members can be portrayed and analysed, thus enabling us to identify how its religious identity has been shaped.

\section{Islam for Children (the End of 1974): From Kaidab Baghdadiyah to Qiroati}

Islamic teachings, provided by PPME's boards for the children (4-12 years old) of its members and sympathizers, consist of basic subjects of Islamic faith, Islamic pillars, Qur'anic recitation, Islamic history, Islamic etiquettes, Islamic Jurisprudence, and short prayers. ${ }^{4}$ The Qur'anic recitation ${ }^{5}$ has drawn most attention of the PPME's boards. This has resulted in three sources for the Qur'anic lesson which also is frequently recommended throughout Indonesia.

The capabilities of reciting the Qur'anic verses and of understanding their meanings were considered important by most Muslims. ${ }^{6}$ Therefore, the children's ability to do so have been considered crucial for the future of PPME. ${ }^{7}$ Since the end of 1974 the Qur'anic lesson for children had drawn the PPME's boards' attention. ${ }^{8}$ To achieve this goal, the lesson is set up as part of the weekly programs of PPME and scheduled either in Saturday or Sunday afternoon --depending on the arrangement of the boards of each branches. The children have been given free days according to those of their schools. ${ }^{9}$ However, only little is known about references used for the lesson since early 1990s. ${ }^{10}$ The only available

4 A. Firdaus Mas'udi, Laporan Kegiatan-kegiatan Kepengurusan Periode 1997-1998, PPME The Hague, The Hague, 07 November 1998, p. 16.

5 W. A. R. Shadid and P. S. van Koningsveld, Moslims in Nederland (Alphen aan den Rijn: Samson Stafleu, 1990), p. 121.

${ }^{6}$ Ruud Strijp, Om de Moskee (Amsterdam University, Ph. D Thesis, 1998), p. 151.

7 T. Thoha Machsun, Laporan Pertanggung-Jawaban Program Kerja PPME Cabang Den Haag Periode 2000-2002 (The Hague: PPME, September 1, 2002), Appendix 8.

${ }^{8}$ Laporan Kerja 1973-1976 PPME the Netherlands (The Hague: PPME, July 31, 1976), p. 8.

9 Machsun, Laporan Pertanggung-Jawaban Program Kerja PPME, Appendix 8, n.p.

10 A. H. Maksum, Laporan Umum Pengurus PPME Wilayah Nederland 1986-1988 pada Musyawarah PPME Wilayah Nederland ke-5, 26-27 November 1988, (The Hague: 
reference was Kaidah Baghdadiyah [Q'àidah Baghdādiyya, Baghdad Method], ${ }^{11}$ written by Abū Manșūr Hifẓ al-Fikrì al-Baghdādī which consists of thirty parts (juz) of the Qur'an. ${ }^{12}$ This world-wide method of reciting the Qur'an emphasizes the capability of recognizing and pronouncing the Arabic alphabets from letters to sentences with their diacritical marks, ${ }^{13}$ but with this children spend too much time to achieve such a capability. ${ }^{14}$ Children learning the Qur'an with the method would spend two to five years. ${ }^{15}$ This duration depend on their diligence, but they still need two or three years. ${ }^{16}$ In spite of its time consuming, this method has been used by Muslim children in Indonesia. ${ }^{17}$ Until the end of 1980s the method was still in scene in the country. ${ }^{18}$

The mid 1990 marks more serious concern of the PPME's boards on the Qur'anic lesson. The children of the members of PPME in The Hague took Cara Cepat Belajar Membaca al-Qur'an (the Fast Method of Learning Reciting the Qur'an) called "Iqra" (Read!), written by an Indonesian writer, As'ad Humam. ${ }^{19}$ The use of Iqra for the children in the PPME was few years later than the experience of the same method

PPME, November 27, 1988), pp. 19-20, A. Naf'an Sulchan, Laporan Pertanggung-Jawaban Program Kerja PPME Wilayah Nederland Periode 1997-1999 (The Hague: PPME, 2000), 9, and see also: Mas'udi, Laporan Kegiatan-kegiatan Kepengurusan Periode 1997-1998, pp. 16-17.

11 A. Naf'an Sulchan, interview, The Hague, December 11, 2011.

12 Dirjen Bimbaga, Sejarah Pendidikan Islam di Indonesia (Jakarta: Depag, 1986), p. 51.

13 Mahmud Yunus, Metodik Khusus Bahasa Arab Jakarta: P. T. Hida Karya Agung, 1983), pp. 6-7.

${ }^{14}$ Shahrin Awaludin, "Kaedah Pengajaran al-Qur'an Masa Kinı", in http:/ / az-zair. blogspot.com/2010/09/kaedah-pengajaran-al-Qur'an-masa-kini.html, accessed June 26, 2011.

15 Yunus, Metodik Khusus, p. 35.

16 Dirjen Bimbaga, Sejarah Pendidikan Islam, p. 51.

17 See also: Muhammad Amin, Kemampuan Anak-anak Membaca al-Qur'an (Suatu Studi di Kabupaten Aceh Tenggara) (Banda Aceh: Pusat Pengembangan Penelitian Ilmu-ilmu Sosial Universitas Syiah Kuala, 1993), pp. 25-27.

18 Yunus, Metodik Khusus, 33, and see also Mangun Budiyanto, "Efektifitas Metode Iqra' dalam Pembelajaran Membaca al-Qur'an di TKA-TPA AMM Kotagede Yogyakarta”, in http://mangunbudiyanto.wordpress.com/2010/07/26/efektivitas-metodeiqro $\%$ E2\%80\%99-dalam-pembelajaran-membaca-al-qur $\% \mathrm{E} 2 \% 80 \% 99$ an-di-tka$\% \mathrm{E} 2 \% 80 \% 93$-tpa- $\% \mathrm{E} 2 \% 80 \% 9 \mathrm{Camm} \% \mathrm{E} 2 \% 80 \% 9 \mathrm{D}$-kotagede-yogyakarta/, accessed January 4, 2011.

19 Sulchan, interview, The Hague, December 11, 2011. 
used in Indonesia, i.e. from $1988 .{ }^{20}$ This means that the PPME's board in The Hague did not neglect the Indonesian development in the Qur'anic lesson. Up to now, it remains a recommended single reference in the country. Similarly, the PPME in Amsterdam still uses the Iqra' method until now.

Since the end of 1998 the children of the PPME's congregation in Amsterdam has been taught with Iqra' method for their Qur'anic lesson. At the end of the year Siti Atma, a member of the association who is responsible for the lesson, brought the Iqra' from Indonesia and offered it to the board of the PPME in Amsterdam. Atma did not need to convince the PPME board over the effective use of Iqra'to learn Qur'anic recitation. Therefore, when the method was applied and considered an apt to the desire and the time availability of the learners, the usage of the method was sustained. The reason was that it was, according to Siti Fatimah (a chairperson of educational division of PPME in Amsterdam), a simple and easy method for Muslim children living in the Netherlands. ${ }^{21}$ Even though this method was not as a simple and easy as she argued, the children must focus on how to recite Arabic words and repeat the words under the guidance of their teachers; they need one year to be able to recite the Qur'anic verses. ${ }^{22}$ The children indeed save time. Thus, this

20 Budiyanto, "Efektifitas Metode Iqra", in http://mangunbudiyanto. wordpress.com/2010/07/26/efektivitas-metode-iqro\%E2\%80\%99-dalampembelajaran-membaca-al-qur $\%$ E2\%80\%99an-di-tka-\%E2\%80\%93-tpa$\% \mathrm{E} 2 \% 80 \% 9 \mathrm{Camm} \% \mathrm{E} 2 \% 80 \% 9 \mathrm{D}$-kotagede-yogyakarta/,accessed January 4, 2011, and see: As'ad Humam, Cara Cepat Belajar Membaca Al-Qur'an (Yogyakarta: Team Tadarus AMM, 1994), and see also Muhammad Amin, Kemampuan Anak-anak. Membaca al-Qur'an, 25-27. This Iqro method has also been introduced in Malaysia through Indonesian activists. See Mangun Budiyanto, "Pedoman Penyelenggaraan Taman Pendidikan al-Qur'an", in http://mangunbudiyanto.wordpress.com/2010/07/26/efektivitasmetode-iqro $\%$ E2 $\% 80 \% 99$-dalam-pembelajaran-membaca-al-qur $\%$ E2 $\% 80 \% 99$ andi-tka- $\%$ E2 $\% 80 \% 93$-tpa- $\%$ E2\%80\%9Camm $\%$ E2\%80\%9D-kotagede-yogyakarta/, accessed May 16, 2013, and see Shahrin Awaludin, Kaedah Pengajaran al-Qur'an Masa Kini, in http:/ / az-zair.blogspot.com/2010/09/kaedah-pengajaran-al-Qur'an-masa-kini. html, accessed 26 June 26, 2011.

${ }^{21}$ Fatimah, interview by phone, December 23, 2011.

22 Budiyanto, "Efektifitas Metode Iqra", in http://mangunbudiyanto. wordpress.com/2010/07/26/efektivitas-metode-iqro\%E2\%80\%99-dalampembelajaran-membaca-al-qur $\%$ E2\% $80 \% 99$ an-di-tka- $\%$ E2\%80\%93-tpa$\% \mathrm{E} 2 \% 80 \%$ Camm $\% \mathrm{E} 2 \% 80 \% 9 \mathrm{D}$-kotagede-yogyakarta/, accessed January 4, 2011. 
method has been being considered effective for the children who have no much time for learning the Qur'an, due to their obligatory in pursuing formal education during the week days. ${ }^{23}$ As a consequence, the iqra' is used untill 2005 for the children of PMME Amsterdam (Euromuslim), and 2011 in PPME al-Ikhlash.

After conflict within the PPME Amsterdam by mid 2005, there has been a change of selecting reference employed for the Qur'anic lesson. Contrary to the choice of PPME al-Ikhlash Amsterdam, the board of PPME Amsterdam considered the Iqra is insufficient to achieve a correct and fluent pronunciation of the children in reciting the Qur'an. ${ }^{24}$ In fact, in addition to be able to recite the Qur'anic verses in an effective time, they are obliged to be able to recite the verses fluently --this is the condition for their move to another level. ${ }^{25}$ This concern has contributed to choose another method focusing more on the latter capability. "Metode Praktis Belajar Membaca al-Qur'an (the Practical Method of Learning Reciting the Qur'an)" of Qiroati (My Reading) written by another Indonesian author, i.e. Dachlan Salim Zarkasy, replaces the Iqra. ${ }^{26}$ On the other hand, the PPME in The Hague, and PPME al-Ikhlash opted Iqra' untill 2011. ${ }^{27}$ The usage of Qiroati method in PPME Amsterdam has been begun after the coming of an imam of tarawith prayers invited from Indonesia, Khoirul Muttaqin ${ }^{28}$ in Ramadan 2005. The selection was as a result of PPME Amsterdam's board's contact with him regarded capable of reciting the Qur'an, and having applied the method for the learners of Qur'anic recitation in his family pesantren (Islamic boarding school) in Jepara, named Roisah (abbreviated from Robithoh Islamiyyah [Islamic Bond]). ${ }^{29}$ Similarly, Astin, the vice co-ordinator of da'wa activity of PPME

23 Siti Fatimah, interview by phone, December 23, 2011.

24 Astin (Da'wa Coordinator of PPME Amsterdam), interview, Almere, December 10, 2009.

${ }^{25}$ Dachlan Salim Zarkasyi, Qiroati Metode Praktis Belajar Membaca al-Qur'an (Semarang: Roudlatul Mujawwidin, January 1990), n.p.

${ }^{26}$ Astin, interview, December 10, 2009.

27 Majlis Dzikir, Mededeling (Amsterdam: PPME Amsterdam, November 3, 2005), n.p.

${ }^{28} \mathrm{He}$ is able to memorise the Qur'an by heart, and a graduate of Institute for Islamic Knowledge and Arabic (LIPIA) of Jakarta. Khoirul Muttaqin, interview, Depok, West Java, March 9, 2010.

29 Abdul Aziz Balbaid, interview, Amsterdam, July 28, 2008. 
Amsterdam, argued that the most reason for the change was that the Qiroati method in emphasising pronunciation of fluency is helpful, in addition to facilitating its learners to achieve their fast reciting the Qur'an. ${ }^{30}$ Up to present in this PPME, the children who have been grouped into their level of achievements have been provided the Qur'anic lesson using the Qiroati on every Sunday afternoon. ${ }^{31}$

It is noteworthy that sources for Qur'anic recitation are Qäida Baghdàdì, Iqra' and Qiroati, references commonly found in Indonesia. This usage signifies that PPME's boards and members deem Indonesian Islam in high regard. They do not erase their memory about indonesia, thus resulting in their selection of the references - memory directing preference $^{32}$ without the dictates of PPME's centre board but the imitation of practices in the field which have been applied in Indonesia.

\section{Ikbtilat in Indonesian Speaking Group (Early 1975): from Inevitability to Necessity}

Islamic subjects are given to PPME's Indonesian speaking group in the last weekend of month (since early 1975.) In 1970s no dominant topic for this weekly activity in the houses of its members in the Hague and its surrounds. Instead, diverse Islamic subjects come in their mind. ${ }^{33}$ Thus, in each gathering there would be more than one subject to be dealt with. Then, after purchasing a musalla (a room of prayer) called al-Ittihaad (Integration) in October 1982, the group discusses Islamic subjects in the musalla rather than in the houses of the PPME's members. Similar to the period of 1970s, only a little was known about Islamic subjects in 1980s. ${ }^{34}$ Only after 1993 a certain design came in the scence. Speakers invited for the activity were requested to deliver a certain theme of Islamic subjects

30 See: Zarkasyi, Qira'ati, n.p., and Astin, interview, December 10, 2009.

31 Astin, interview, December 10, 2009.

32 Cf. Esra Demirci Akyol, the Role of Memory in the Historiography of Hatay: Strategies of Identity Formation through Memory and History (Germany: VDM Verlag Dr. Muller Aktiengesselshaft \& Co. KG and Licensors, 2009), p. 19.

33 Laporan Kerja 1973-1976 (The Hague: PPME the Netherlands, July 31, 1976), p. 8 .

34 Maksum, Laporan Umum Pengurus PPME Wilayah Nederland 1986-1988 (The Hague: PPME, November 27, 1988), pp. 32-3. 
in order to avoid delivering the same repetitive subjects ${ }^{35}$ - there was no demand posed by its organizer to the speakers for delivering a certain Islamic field such as Islamic Law, theology or mysticism (tasawwuf). The weekly gathering was better arranged since the late 1990s. The subjects were decided prior to the time of group gathering. As a result, diverse Islamic subjects, from Islamic faith, etiquettes, jurisprudence, to history were taught. The speakers were assigned the task of delivering Islamic subjects. For instance, Islamic jurisprudence was taught by A. Hambali Maksum; Islamic etiquettes by M. Isyak; Islamic history by M. Chaeron; and Islamic faith by A. Naf'an Sulchan. Other members of PPME such as Asief, Ishom and A.F. Mas'udi also helped these teachers. ${ }^{36}$ This owed to the presence of the Indonesian mosque of al-Hikmah (Wisdom), which was purchased in 1996 and was under the organization of its own board. The PPME's board has been permitted to use the mosque for the activities, especially, of its branch in The Hague. Despite no primary books recommended by the PPME, and the teachers have freedom, ${ }^{37}$ on the basis of voluntariness the teachers have, up to 2011, to do the job. ${ }^{38}$

Islamic sermons of for Indonesian speaking group in the PPME's members and sympathizers in The Hague are attended by men and women who occupy the same room, and are not separated with satir (cloth-made room partition) known as ikbtilat (mingling in one place without sätir between male and female who are not mahărim [a plural form of mahram]). ${ }^{39}$ In fact, such ikbtilat is, according to reformist Muslims such as Ibn Taymiyyah and A. Hassan (PERSIS), forbidden. Ibn Taymiyya argues in his Majmü' al-Fatäwā, "the mingling of man and woman will initiate temptation (fitna). Man who mingles with woman like

${ }^{35}$ Mohammad Isyak, Laporan Pertanggung-Jawaban Pengurus PPME Wilayah Nederland Periode 1994-1996 (The Hague: PPME the Netherlands, June 21, 1997), p. 7.

36 Ibid., p. 19.

37 Sulchan, Interview, December 11, 2011.

38 Machsun, Laporan Pertanggung-Jawaban Program Kerja PPME Cabang Den Haag, Appendix 9, pp. 1-3, Sio Raboen et al, Het Jaar verslag van het Bestuur PPME Den Haag Periode 2002 - 2004 (The Hague: PPME, April 3, 2005), 8-9, and Aaman Sulchan, PPME Den Haag: Het Verslag 2005 en Vooruitzichtt 2006 (The Hague: PPME, May 29, 2006), n.p.

39 The Editors of As-Sunnah (a Salafi Magazine), "Bahaya Laten Ikhtilat", in As-Sunnah 3, Year XI, 2007, p. 12, and see also: Ummu Salamah, Ikbtilath dan Bahayanya, in http://almuslimah.wordpress.com/2008/04/14/ikhtilath-dan-bahayanya/, accessed January 15, 2012. 
fire put close to wood"40 whereas Hassan asserted, "Islamic viewpoints principally forbid male Muslim to see female Muslim, and they are required to separate the two different sexes in their social interaction. ${ }^{41}$ These viewpoints suggested that it is unlawful for two different sexes to be in one place at the same time. This is contradictory to a gathering model in acquiring Islamic knowledge of PPME which are in general held in the way of ikbtilat (mixing men and women).

The phenomenon of ikhtilat in PPME of The Hague, that is also found in other branches of PPME al-Ikhlash in Amsterdam (not PPME Amsterdam taking at Ekingenstraat 3-7, Osdorp) and PPME ar-Rahman (the Merciful) in Breda, can be noted. Firstly, what Waardenburg stated that Muslims in Western Europe encountered financial problems, not only for the running of the activities of their associations, but also for their survival, ${ }^{42}$ especially in the $1970 \mathrm{~s} .{ }^{43}$ Ik $h$ tilat took place due to the lack of facilities for their gathering. ${ }^{44}$ Prior to the purchase of the musalla of al-Ittihaad in 1982, they used to hold their gatherings in order to acquire Islamic knowledge in their own houses. This condition led them (male and female members) to gather in the houses in the way of ikbtilat in the sense of separation of their seats but not their room. This way was still implemented even though PPME's board has musalla in 1982. This also occurred due to the similar reason for the period before the purchase of the musalla, i.e. this place of worship provided only a single living room for gathering. ${ }^{45}$

Subsequently, the like-abovementioned gathering went on even though the PPME's board in The Hague had been permitted to use the Indonesian mosque al-Hikmah since September 1996. In this mosque there are, at least, three rooms available which can be used for its religious gatherings. Unlike the reason of the previous periods, the

40 As-Sunnah 3, 2007, p. 12.

41 A. Hassan, Soal-Djawab tentang Berbagai Masalah Agama, 2nd Ed. (Bandung: C. V. Dipenegoro, 1969), pp. 661-681.

42 J. D. J. Waardenburg, "Muslim Associations and Official Bodies in Some European Countries", in W. A. R. Shadid and P. S. Van Koningsveld, The Integration of Islam and Hinduism in Western Europe (Kampen: Kok Pharos Publishing House, 1991), p. 31.

43 See: Nico Landman, Van Mat Tot Minaret: de Institutionalisering van de Islam in Nederland (Amsterdam: VU Uitgeverij, 1992), p. 42.

44 Maksum, interview by phone, The Hague, December 20, 2011.

45 Ibid. 
ikhtilät gathering, which is no longer inevitability and contradictory to the abovementioned reformist viewpoints, are held for two interests. To begin with, the Dutch muslim converts have joined the PPME due to such a gathering - no separation between women and men. ${ }^{46}$ For instance, Hennie Hammink, who was a chairperson of the PPME in The Hague (2011-2012), converted to Islam in early September 1995 in the musalla of al-Ittihaad under the guidance of Indonesian preacher called Sa'ad Syamlan, who was invited to deliver Islamic speech in the commemoration of the Prophet Muhammad's birthday on 3 September 1995 in the Hague. Hammink converted to Islam due to his own desire of searching for his meaningful life. He found it when attending the weekly ikbtilat gatherings held in the musalla of al-ittihaad. Islam delivered in the gathering stimulated him to assert: "Ik heb mezelf in Islam gevonden (I have found myself in Islam)." ${ }^{47}$

Secondly, al-Ghazali's al maslaha al-häjizya (the necessary common good), i.e. the common good that is complementary for the acquisition of goodness and necessary for adjustment to prevailing conditions, ${ }^{48}$ is, seemingly, implemented. Maksum argues that such ikhtilat. was held in order to hinder strict separation between the PPME's female and male members [dichotomizing them], thus being adjusted to the condition of the Dutch society. ${ }^{49}$ This integrated gathering will not, according to him, lead people to conduct sins (ma'siyya) before the crowd. ${ }^{50}$ Despite improper analogy due to a different context, Maksum adds that such a practice of ikhtilat could also be found in performing hajj. This adjustment has relies upon a common good (maslaha), especially, for the association rather than purely upon the Prophet Traditions. ${ }^{51}$ Similarly, A. Naf'an Sulchan states that in propagating Islam we need to deliver Islamic teachings in accordance with the traditions of PPME's members with

${ }^{46}$ Ibid., and Sulchan, interview, December 11, 2011.

47 Abdul Hamid (a Muslim name of Henni Hammink), "Ik Heb Mezelf in Islam Gevonden”, in Al-Ittihaad 44, December 1995, p. 23.

48 See: Abu Hamid Muhammad ibn Muhammad al-Ghazali, Al-Mustasfā min Tlmi al-Usüli, 1st ed. (Beirut: Dar al-Fikri, n.y.), pp. 286-290, and see also: Tariq Ramadan, Western Muslims and the Future of Islam (Oxford: University Press, 2004), p. 39.

49 Maksum, interview by phone, December 20, 2011.

${ }^{50}$ Ibid.

${ }^{51}$ Ibid. 
having differnt ethnics and religious backgrounds. Radical change should be avoided. Separating them according to their gender is radical change. He goes on to argue that when the members asked for him to dance in the ikbtilat gathering he would accept their request. ${ }^{52}$

Given the facts, ikbtilat that was firstly been there due to the lack of accommodation is retained in the PPME of The Hague because of its regard to its members' characteristics and the context of the Netherlands. This will contribute to future existence.

\section{Conducting Islamic Marriages: Islamic and Positive Laws (1975)}

The PPME's board held the Islamic marriages of Muslim brides and bridegrooms since March 29, 1975. ${ }^{53}$ Since then, couples' marriages has been part of its incidental programs. ${ }^{54}$ The Islamic marriages that have been held by the PPME's boards in the Netherlands year by year were not well registered, thus providing no information on their numbers. For instance, between 1976 and 1979 they held Islamic marriages for fifteen couples, ${ }^{55}$ five couples between 1984 and 1986, ${ }^{56}$ four couples between 1997 and $1998,{ }^{57}$ fifteen couples between the year 2000 and $2002,{ }^{58}$ twelve couples between 2002 and 2004, ${ }^{59}$ and seven couples in $2005 .{ }^{60}$ In 2008 and 2009 there were two couples getting married under the arrangement of the PPME's boards - in the former it was facilitated by the PPME's board in The Hague whereas the latter marriage was held by the board of PPME Amsterdam. All of the abovementioned marriages were held

\footnotetext{
52 Sulchan, interview, December 11, 20011.

${ }^{53}$ Laporan Kerja 1973-1976 PPME the Netherlands (The Hague: PPME, July 31, 1976), 9 and 16.

${ }^{54}$ DPP YMAE, Laporan Kerja 1976-1979 (Achen, West Germany: YMAE, June 1, 1979), p. 6.

55 Ibid.

${ }^{56}$ Maksum, Laporan Umum Pengurus PPME Wil. Nederland 1984-1986 (The Hague: PPME, November 23, 1986), p. 34.

57 Mas'udi, Laporan Kegiatan-kegiatan Kepengurusan, p. 27.

${ }_{58}$ Machsun, Laporan Pertanggung-Jawaban Program Kerja PPME Cabang Den Haag, Appendix 4, pp. 2-3.

${ }^{59}$ Sio Raboen et al, Het Jaar verslag van het Bestuur PPME Den Haag, Appendix of Secretariat, n.p.

${ }^{60}$ Aaman Sulchan, PPME Den Haag: Het Verslag 2005 en Vooruitzicht 2006 (The Hague: PPME, May 29, 2006), n.p.
} 
either in The Hague, Amsterdam or Rotterdam in the houses of brides, the mosque of al-Hikmah, the musalla of al-ittihaad, or the building under the PPME Amsterdam's administration.

The couples married under the organization of PPME's boards were not only the marriages of Indonesian but also those of mixednationality Muslim couples. For instance, Herbert R. Verhey (Dutch) married to Elly Agustina (Indonesian) on June 10, 2000; Tony Ochtman (Indonesian) married to Suprapti (Indonesian) on September 25, 2000; Shahril Rizal bin Moh. Shahiri (Malaysian) married to Mastura binti Moh. Zain (Malaysian) on January 21, 2001; Haroon Muna Ghulam Mirza (British) married to J. J. A. C. F. Maria Frumau (Dutch) on June 16, 2001; and Teguh Moljono (Indonesian) married to Suzi Wiraatmadja (Indonesian) on February 2, 2002. From this period of 2000-2002, the number of mixed-nationality marriages surpassed that of Indonesian married couples. In this period Indonesian couples are only two. ${ }^{61}$

In conducting Islamic marriages, in addition to acting either as the wali hakim (representing the authorized person), witness or registrar, ${ }^{62}$ the boards of PPME have set up simple requirements for the Muslim couples who wished to get married under the board's arrangement. This easiness has been in line with the principle of PPME in marriage affairs, namely, "making the performing of marriage easy and making the performing of divorce difficult" - a principle that favors the goal of the marriage, i.e. "denouncing fornication as illegal". ${ }^{63}$ This has been aimed to address that the performing marriage primarily relies upon the requirements referring to Islamic Law, and takes other official administrative requirements such as birth document and the status of citizenship into account. ${ }^{64}$ Therefore, when the primary requirements in Islamic Law such as the attendance of bride and bridegroom, wali (the authorized person to wed the bridegroom) from the bride, two Muslim male witnesses, and consent-granted (ijab-

${ }^{61}$ Machsun, Laporan Pertanggung-Jawaban Program Kerja PPME Cabang Den Haag, Appendix 4, p. 2.

62 DPP YMAE, Laporan Kerja 1976-1979, p. 6.

${ }_{63}$ Maulana Abul A'ala Maudoodi, the Laws of Marriage and Divorce in Islam (transl.), 3rd ed. (Kuwait: Islamic Book Publishers, 2000), p. 6.

${ }^{64}$ Mas'udi, Laporan Kegiatan-kegiatan Kepengurusan, p. 23. 
qabul $)^{65}$ are fulfilled, the marriage can be conducted. As a consequence, the marriages would be valid according to Islamic Law and the married couple would be provided their marriage book from the board after fulfilling their administrative requirements such as paying some amounts of money, 50 Euro for PPME's members and 90 Euro for non-members of PPME. ${ }^{66}$

Indonesian people in the Netherlands got married with people of other nationalities. In relation to such marriages, since 1975 Indonesian law on marriage has been taken into consideration by the boards of the PPME. ${ }^{67}$ As a result, in 1980s some marriages of the Indonesian couples under the organizing of PPME's board had been in co-operation with the Indonesian Embassy's authorized staff ${ }^{68}$ - at least the Embassy's staff was informed and invited to attend the marriages. ${ }^{69}$ Then, the late $1990 \mathrm{~s}$ was the starting point for a more serious effort to deal with Indonesian Law, thus conducting Islamic marriages to be part of PPME's programs. ${ }^{70}$ This concern contributed to the fact that since the early 2000s Indonesian marriages have been conducted based upon not only Islamic Law but also Indonesian Law in order to avoid breaking the positive law on marriage prevailing in Indonesia, ${ }^{71}$ namely the Indonesian Law number 1 of $1974 .{ }^{72}$ As a consequence, the married couples will gain legal documents of their Islamic marriage not only from the board of the PPME but also from the authorized officer of the Indonesian Embassy in the Netherlands. ${ }^{73}$ This implies that the boards in holding such Islamic marriages of the

${ }^{65}$ See: Dirjen Bimbingan Masyarakat Islam dan Urusan Haji, Petunjuk Pelaksanaan Perkawinan di Luar Negeri (Jakarta: Depag RI, 1989)., Appendix 1, pp.: 35-37.

${ }_{66}$ Machsun, Laporan Pertanggung-Jawaban Program Kerja PPME Cabang Den Haag, Appendix 4, p. 4.

${ }^{67}$ Laporan Kerja 1973-1976 (The Hague: PPME, July 31, 1976), p. 9.

${ }_{68}$ Maksum, interview by phone, December 20, 2011, and Sufjan Ollong, interview, Ridderkerk, May 5, 2009.

${ }^{69}$ Ollong, Interview, May 5, 2009.

${ }^{70}$ Mas'udi, Laporan Kegiatan-kegiatan Kepengurusan, p. 23

${ }_{71}$ Machsun, Laporan Pertanggung-Jawaban Program Kerja PPME Cabang Den Haag, Appendix 4, p. 2, and Nur Hasyim (a Local Staff of Indonesian Embassy for Religious Affairs for the Netherlands), interview, Mariahove, The Hague, December 5, 2008.

${ }^{72}$ See: Dirjen Bimbingan Masyarakat Islam dan Urusan Haji, Petunjuk Pelaksanaan Perkawinan, pp. 3-5.

${ }^{73}$ Mas'udi, Laporan Kegiatan-kegiatan Kepengurusan, p. 23. 
Indonesian couples have invited the embassy's officer especially as the registrar in addition to their role as the official recorder and supervisor of the ceremony- this procedure is a must for the couples who will conduct their marriage under the Indonesian bureaucracy. ${ }^{74}$

A consulate marriage that involves a Dutch citizen is not recognized in the Netherlands", ${ }^{75}$ and, on the other hand, Indonesian government recognizes marriage of Indonesian couple or an Indonesian overseas on a condition that it is according to the positive marriage law of the country. ${ }^{76}$ In fact, Islamic marriage under the PPME arrangement is conducted as simple as possible on the basis of Islamic Law. Therefore, the contradictory positive laws of two countries do not bother the arrangement. As a consequence, the PPME's provision of marriage book which can serve as proof of marriage of couple of Indonesians or mixed-nationalities has nothing to do with the positive laws on the marriage, but of proof of Islamic marriage. Nevertheless, for indonesians couple, the PPME will invite the marriage registrar of the Indonesian Embassy in the Netherlands. Then, for the mixed-nationality couple (Dutch-Indonesian), the couple is required to marry in front of Dutch officer. This can be seen from the following experience of an Indonesian girl, Siti Rakhmawati.

Rahmawati is the coordinator of an-Nasyid Remaja (Youth's Islamic Anthem) of PPME. She married Saleh Safruddin (a Dutchman of Pakistan descent) on October 24, 2008. Having been clarified that bride, bridegroom, wali, and witnesses were ready, the authorized person to marry the couple should be her father. This task can be conducted by another authorized person appointed by her father. ${ }^{77}$ Due to the fact that her father already deceased, the task went to his brother or the

${ }^{74}$ See: Dirjen Bimbingan Masyarakat Islam dan Urusan Haji, Petunjuk Pelaksanaan Perkawinan, pp. 3-5; Hasyim (a Local Staff of Indonesian Embassy for Religious Affairs), Interview, Mariahoeve, The Hague, and Maksum, interview by phone, December 20, 2011.

75 See: Nathal M. Dessing, Rituals of Births, Circumcision, Marriage, and Death among Muslims in the Netherlands (Leuven: Peeters, 2001), p. 90.

${ }^{76}$ Dirjen Bimbingan Masyarakat Islam dan Urusan Haji, Petunjuk Pelaksanaan Perkawinan, p. 5.

77 See: Ibid., p. 35. These requirements of Islamic marriage forwarded by the Indonesian Government are in line with those of al-Syāfíc ${ }^{\top}$. See: Muhammad ibn Idrīs al-Syāfiłī, Al-Ummu, 2nd ed. (Beirut: Dār al-Fikri, 1983), pp. 13 and 23. 
bride's uncle - this is, at least in accordance with the opinion of al-Syāfici arguing that marriage authority should come from father's line. ${ }^{78}$ As a consequence, there was no obligation for the PPME to conclude their marriage when there was no request from her family. This practice shows that Islamic law of marriage was met by the PPME. Subsequently, after concluding their marriage in which ijäb-qabül was conducted between the wali and the bridegroom, the couple was obliged to sign their legal documents prepared by the PPME's registrar. Thus, the supervision and record taken by the PPME's board comply the marriage law of Indonesia. ${ }^{79}$ Lastly, the ceremonial speech (khutbatu al-nikäh) for marriage, Islamic speech and closing prayer were delivered by the assigned figures of the PPME.$^{80}$ Based upon these facts, there is no need for the authorized marriage officer of the Indonesian embassy to do the tasks as conducted by the PPME's. When one of couple hold Dutch nationality, it thus requires a Dutch official marriage - the couple should be legalized in front of the authorized Dutch officer for marriage affairs. ${ }^{81}$

The facts show that conducting marriage under the PPME's arrangement has taken both the Indonesia marriage law and Islamic law into account. This indicates that the foundation of the organisation along with the nationality backgrounds of the couples have drawn special attention of the PPME's boards in providing assistance. Thus, Indonesian and Dutch regulations on the marriage subject are still pursued

\section{Assisting Converts (Early 1980s)}

PPME's boards provides assistance to Islamic convert since the early 1980s. ${ }^{82}$ This assistance is available in the centers of PPME, such as the musalla of al-Ittihaad and al-Hikmah (the Hague), PPME Amsterdam (later called at-Taqwa), and another place, for instance, the mosque of Baiturrahman (the House of the Merciful) in Ridderkerk. Kind assistance

78 Ibid., pp. 14-15.

79 Dirjen Bimbingan Masyarakat Islam dan Urusan Haji, Petunjuk Pelaksanaan Perkawinan, pp. 3-5.

80 A. Naf'an Sulchan (a Witness), interview, The Hague, December 11, 2011.

81 See: Dessing, Rituals of Births, Circumcision, Marriage, and Death, p. 93.

82 A. Hambali Maksum, Laporan Umum Pengurus PPME Wil. Nederland 1984-1986 pada Musyawarah PPME Wil. Nederland 23-11-1986 di Den Haag (The Hague: PPME, November 23, 1986), p. 34. 
has been given on the ground of converts' needs. What Anne Sofie Roald argues that "in modern times... conversion to a religion has been marked by individual choices" $" 83$ seems to be the reasons of Islamic converts under the guidance of PPME's person knowledgeable of Islam. In the period of 1980s the main reason for the conversion was to prepare their marriage to muslim partner. ${ }^{84}$ For instance, between 1984 and 1986 five of nine Muslim convert, because they wanted to marry a female or male Muslim. ${ }^{85}$ Information about Islamic marriages held by the PPME's boards in the 1990s was not known. In 2000s, the argument of 1980s come again. For instance, in the mosque of al-Hikmah between 2000 and 2002 there were twelve Islamic converts, whereas in 2005 four converted to Islam for the reason of marriage. ${ }^{86}$ This means that common reason for Islamic conversion in the Netherlands in 1990s, is marriage. ${ }^{87}$

In addition to the aforementioned reason of marriage, conversion under the service of PPME, comes for three other reasons. The conversion of Hammink was due to his own consciousness of searching for his meaningful life --a psychological rationale found in his statement "Ik heb mezelf in Islam gevonden". ${ }^{88}$ Secondly, the twelve converting to Islam in 2000s aimed at preparing their marriage. Three others of them converted to Islam for two other reasons. The first was to become a member of the PPME in The Hague ${ }^{89}$--this reason is similar to that of a Dutch person converting to Islam on March 17, 2009 held in the PPME Amsterdam under the guidance of Fahim, a Dutch speaking gathering.

83 See: Anne Sofie Roald, New Muslims in the European Context (Leiden-Boston: Brill, 2004), p. 80.

${ }^{84}$ Salah Salem Abdel Razaq, "Neo-Muslim Intellectuals in the West and Their Contributions to Islamic Thought and the Formation of Western Islam”, Ph. D. Thesis, Leiden University, 2005, p. 13.

85 Maksum, Laporan Umum Pengurus PPME Wil. Nederland 1984, pp. 33-34.

86 Sulchan, PPME Den Haag, n.p.

87 Gé Speelman, "Mixed Marriages", in Gé Speelman et al (eds.), Muslims and Christians in Europe Breaking New Ground (Kampen: Uitgeverij Kok, 1993), p. 140, and see also: Sefa Baçi, Mixed-Marriage in the Netherlands (Leiden University, Master Thesis, 1999), p. 64.

88 Al-Ittihaad 44, December 1995, p. 23.

89 Machsun, Laporan Pertanggung-Jawaban Program Kerja PPME Cabang Den Haag, Appendix 4, p. 1. 
The second was to have enjoyable life in Indonesia. ${ }^{90}$ Islamic marriage under the board of PPME's organizing marriage will enable the couple to gain Islamic legal document of their marriage from PPME, thus enabling them to respond to questions raised by Indonesian family. This is due to the couples' preference for their Dutch official marriage, ${ }^{91}$ which is not on the basis of Islamic Law. The converts' arguments for their Islamic conversion are individual choices --other reasons, for instance, for being Islamic preachers among Western societies. Achieving political gains is not found among the converts with the auspices of the PPME's board. ${ }^{92}$

Based upon the facts, three arguments for the conversion under the service of PPME, are marital, spiritual, and practical reasons. The assistances of the association's boards for serving Islamic conversion have been accommodative, not only religious but also socio-cultural motivations.

\section{Pengajian Remaja (the Early 1990): Pesantren Kilat, Iqra' and an- Nasyid Remaja}

Since early 1990s the second generation of PPME's members in the Netherlands --the children of the founders and congregations, not the children of those migrating to the country for family re-unification ${ }^{93}$-founded their own group called Pengajian Remaja (Learning Islam for Youths). This group (of children 15-18 years old) was led by Hansyah Iskandar, ${ }^{94}$ speaking both Indonesian and Dutch, graduating from Delft University, and recently having acted as the chairperson of PPME Arrahman Breda (2011). His secretary was Aaman Sulchan, ${ }^{95}$ speaking Indonesian and Dutch, graduating from Leiden University, and the chairperson of PPME in The Hague branch (2005-2010). This group of which mostly spoke Dutch rather than Indonesian came into existence due

90 Ibid.

${ }^{91}$ Maksum, Laporan Umum Pengurus PPME Wil. Nederland 1984, pp. 33-34.

92 See: Razaq, Neo-Muslim Intellectuals, p. 13.

${ }^{93}$ M. Roijackers, "Religious Identity, Integration and Subjective Well-Being among Young Turkish Muslims", in W. A. R. Shadid and P. S. van Koningsveld, Islam in Dutch Society: Current Developments and Future Prospects (Kampen: Kok Pharos Publishing House, 1992), p. 67.

${ }^{94}$ A. Naf'an Sulchan, Laporan Pertanggungawaban Program Kerja PPME/YMAE Nederland Periode 1992-1994 (The Hague: PPME, November 27, 1994), pp. 16-17.

${ }^{95}$ Ibid. 
mainly to their dissatisfaction with the weekly Islamic teaching delivered by the PPME's Islamic teachers in the Indonesian speaking group --the Dutch language used only for the summary of Islamic teaching. ${ }^{96}$ In response to the dissatisfaction, Yani Kurdi and Moch. Chaeron were appointed as advisors of the group in 1990s. ${ }^{97}$ And in 2000s, the new group was under the coordination of Hendriks Réné (the coordinator of the Dutch speaking group called al-Moekminun (the Believers) and Taty Suhartono (the vice chairperson of PPME in The Hague)..$^{98}$

The main reasons for forming the Pengajian Remaja were two folds. It aims to stimulate the PPME's youths to learn Islam independently, and to discuss their religious lives in non-Muslim societies. ${ }^{99}$ To achieve these ends, Islamic teaching programs for youth called Pesantren Kilat (a short course on Islamic knowledge) have been held, bulletin called Iqra' (Reading) was issued. In addition, the group of Pengajian Remaja formed a music group called an-Nasyid Remaja. In relation to the first program, they had been provided Islamic teaching consisting of Islamic faith, etiquette, and law monthly or once bimonthly. For the faith subject, they learned, for instance, three principle subjects, i.e.: Allah, Islam and the Prophet Muhammad. In association with the etiquette, they learn other subjects such as the reasons for the needs to hold Islamic etiquette, the Prophet Muhammad as the best figure of the best etiquettes and the relation of Muslims with the adherents of other religions, and other societies. For shari'a (Islamic Law) they learned obligatory prayers, marriage, and sexual intercourse in Islam. ${ }^{100}$

Pesantren Kilat, performed through formal education or in the

${ }^{96}$ Machsun, Laporan Pertanggung-Jawaban Program Kerja PPME Cabang Den Haag, Appendix 5, p. 6.

${ }^{97}$ Yani Kurdi, Laporan Kerja Seksi Pendidikan dan Kaderisasi PPME Wilayah Nederland Periode 1992-1994 (The Hague: PPME, Maret 28, 1994) p. 3-4, and see also: Hansyah Iskandar et al, Handleiding Pengajian Remaja PPME (The Hague: PPME, 19981999), p. 5.

98 Machsun, Laporan Pertanggung-Jawaban Program Kerja PPME Cabang Den Haag, Appendix 5, p. 2.

99 Yani Kurdi and Dewi Hendriks, Acara Rapat Evaluasi I Dep. Pendidikan dan Da'wah (The Hague: PPME, September 29, 1996), p. 13.

100 Anonymous, "Activiteiten Pengajian Remaja", in Hansyah Iskandar et al, Handleiding Pengajian Remaja PPME (The Hague: PPME, 1998-1999), n. p. 
mosque, ${ }^{101}$ plays a pivotal program of the PPME for its second generation. Therefore, Pesantren Kilat, i.e. commonly developed in Indonesia as place for children in order to learn Islam and improve Islamic knowledge ${ }^{102}$ by staying few days in a certain place, has frequently been held by the PPME. In 1995 this program took place for the first time at van Everdijkstraat 31, Rotterdam on 5 and 6 August. The program used Dutch as the language focuses on Islam and the PPME. ${ }^{103}$ The second one was held in a camp area called Camping Duinhoeve Noordweg 20, Oostvoorne, Rotterdam from 28 to 30 June 1999 attended by 62 participants from all the branches of PPME in the Netherlands. ${ }^{104}$ In the 2000s, the Pesantren Kilat was held several times. The examples were as follows: it was held on September 11, 2002 at the mosque of an-Nur belonging to a Moluccan community in Waalwijk; in 2003 it was held at the mosque of Baiturrahman belonging to the Moluccan community in Ridderkerk; in 2004 it was held on April 30, and May 1-2, 2004 at the mosque of Baiturrahman; ${ }^{105}$ and in 2005 at the mosque of al-Hikmah in the last week of Ramadhan. ${ }^{106}$ As a result, members of the PPME have gained not only diverse Islamic knowledge but also organizational skills by which they will have a leading role in the future. Such achievements can be seen more evident in the example of 1995 Pesantren Kilat elaborated in the following discussion.

Pesantren Kilat held by the PPME is not precisely similar to that held in Indonesia. The PPME however imitates pesantren kilat in Indonesia. ${ }^{107}$

101 See: S. van de Wetering, "The Arabic Language and Culture Teaching Program to Moroccan Children", in W. A. R. Shadid and P. S. van Koningsveld, Islam in Dutch Society: Current Developments and Future Prospects (Kampen: Kok Pharos Publishing House, 1992), 89-100, and see also: Dick Douwes et al, Nederlandse Moslims: van Migrant tot Burger (Amsterdam University Press: Salomé, 2005), pp. 57-59.

102 See: Direktorat Pendidikan Agama Islam pada Masyarakat dan Pemberdayaan Masjid, Panduan Pesantren kilat (Jakarta: Depag, 2004), pp. 1-3, 5-6, 9-10 and 15.

103 Isyak, Laporan Pertanggung-Jawaban Pengurus PPME, 8.

104 Ibid., and see also: Husny Abdul Razaq et al, Programma PPME Jengdkamp (Rotterdam: PPME, June 1996), n.p.

105 Raboen et al, Het Jaar verslag van het Bestuur PPME Den Haag, pp. 10-11.

106 Sulchan, PPME Den Haag, n.p.

107 In Indonesia Pesantren Kilat is an activity of Islamic education in which students and youths can take parts. This activity can be held [such as] by schools, universities, mosques, Islamic educational institutions, and da'wa institutions in short period of time or during their free days. Dirjen Kelembagaan Agama Islam, Panduan Penyelenggaraan Pesantren Kilat (Jakarta: Depag, 2005), pp. 3, 7 and 8. 
The pesantren kilat of 1995 took place in Rotterdam on 5-6 August. ${ }^{108}$ In this program, 35 participants from all the branches of PPME in the Netherlands -Amsterdam, Rotterdam and The Hague- participated. Subjects, introduced mostly in Dutch, were related to both Islam and PPME as a socio-religious association. ${ }^{109}$ In relation to Islam, diverse subjects were taught. Its participants were taught Islamic jurisprudence, worship practices, Islamic history, Islamic faith, Islamic etiquettes, Qur'anic exegesis and the prophet traditions. Pertained to PPME, lectures on its history, roles, functions and orientation were delivered. It is worthnoting that in addition to the subjects on Islam and PPME, the participants were also given an opportunity to explore and discuss their problems related to their experience in their daily lives in the Netherlands. ${ }^{110}$ In addition, participants were also provided organizational subjects for the cadres of the PPME.

In addition to the Pesantren Kilat, the board of the Pengajian Remaja published a Dutch bulletin called Iqra' in 1996. ${ }^{111}$ This bulletin was published bimonthly covering the activities of the pengajian remaja's Islamic sermon. ${ }^{112}$ Iqra' serves as the means for expressing the youth's religious ideas and experiences. As a consequence, most of subjects dealt with in the bulletin were written by the members of the group themselves. For instance, Rachmawati Chaeron (a daughter of PPME's founder, Moch. Chaeron) writes the story of Isra' Miraj (Midnight Journey to the Seven Heavens) of the Prophet Muhammad, whereas Aaman Sulchan (a son of a PPME's leading figure knowledgeable of Islam, A. Naf'an Sulchan) writes the significance of fasting month. Hansyah Iskandar' piece is on the biography of A. Naf'an Sulchan, the leading figure within the PPME. ${ }^{113}$ Their endeavors to present their works in Iqra' indicate that the bulletin serves as the vehicle for the youth not only to express their own Islamic

108 Ditpeka Pontren, Pola Penyelenggaraan Pesantren kilat (Studi Kasus Pondok Pesantren Babakan Ciwaringain, Cirebon, Jawa Barat) (Jakarta: Depag, 2003), pp. 7-8.

109 Isyak, Laporan Pertanggung-Jawaban Pengurus PPME, p. 8. 1995, p. 30.

110 Ifa Chaeron, "Kiprah Remaja Muslim di Belanda", in, Al-Ittihaad 44, December

111 Isyak, Laporan Pertanggung-Jawaban Pengurus PPME, 14, and Euromoslem 46, July 1997, p. 11.

112 Hoofdbestuur, Handleiding PR PPME (The Hague: PPME,1998-1999), p. 8.

113 Iqra' 3, January-February 1998, pp. 5-12. 
points of view, but also to discuss their own life experience. Unfortunately, the publication that had been "new grounds for interaction and mutual recognition" 114 between the PPME's first and second generations and Indonesian Muslim and Dutch in general could no longer be found after the year 2000. ${ }^{115}$

Last but not least, music commonly judged by 'ulamā - either not recommendable or unlawful ${ }^{116}$ - has drawn great attention of the youths. They formed a music group called an- Nasyid Remaja (Youth's Nasyid) since 2006. ${ }^{117}$ This means that their nasyid which resembles a song of praise to God, spirituality, and the glory of Islam, ${ }^{118}$ came much later than the same music in Indonesia which became popular at the end of 1990 s. $^{119}$ This group with the Indonesian way, i.e. its male members frequently wearing koko (cloth with long sleeves and white color) and kopiah (black and rimless cap) included female vocalists in their music. ${ }^{120}$ For instance, this an-Nasyid Remaja took part in the festivity for the commemoration of the birth of the Prophet Muhammad on April 11,

114 See: Dale F. Eickelmen and Jon W. Anderson, "Redefining Muslim Publics", in Dale F. Eickelmen and Jon W. Anderson, New Media in the Muslim World: the Emerging Public Sphere, 2nd Ed. (USA: Indiana University Press, 2003), p.3.

115 Hoofdbestuur, Handleiding PR PPME, pp.4-9.

116 Yusuf Qardawi, Figh al-Gina wal-'Musiqi fi Daw'i al-Qur'an wal-'Sunna (Cairo: Maktaba wa Hiba, 2004), p.25.

117 Ilman Sulchan (one of Nasyid Remaja's Vocalists), interview, The Hague, December 11, 2011.

118 Adjie Esa Poetra, Revolusi Nasyid, 1st Ed. (Bandung: MQS Publishing, 2004), pp.16, 49, and 51.

119 According to Adjie Esa Poetra, nasyid music has existed in Jakarta since mid 1980. The performance of nasyid music has publicly been seen since 1995 . Harmony Voice (Bandung), Snada (One Tone, Jakarta), Suara Persaudaraan (Voice of Brotherhood, Surabaya) and Izzatul Islam (Glory Of Islam, Jakarta) were well known nasyid groups. However, the nasyid reached its popularity in Indonesia when a well-known Malaysian Nasyid Group called Raihan (literally, Sweet Basil) performed their nasyid at Gedung Sasana Budaya Ganesha Sabuga, Bandung at the end of 1990s. Ibid., pp. 57, 71-72, and 117, and see also: Bart Barendregt, "Transnational Soundscapes in Muslim Southeast Asia", in Todd Joseph Miles Holden and Timothy J. Scrase, Medi@sia: Global Medial tion in and out of Context (London and New York: Routledge, 2006), p. 175.

120 Cf. Barendregt, "Transnational Soundscapes in Muslim Southeast Asia", in Holden and Scrase, Medi@sia: Global Medial tion, p. 173. 
2009 held in The Hague ${ }^{121}$ and in the cultural night of an event called Initiatives of Change held in Caux, Switzerland on September 22, 2009. ${ }^{122}$ It was also performed at the anniversary of the mosque Baiturrahman belonging to Moluccan Muslim community in Ridderkerk on October 10, 2009. The reputation of this music group and their performances in many events indicate that the boards of PPME have allowed the music group to countinue its activities. ${ }^{123}$ In so doing, the PPME seems to take stance of the Jurist Ibn Hazm al-Andalusi and the sufi Imam al-Gazali who allowed music in Islam. ${ }^{124}$

The PPME's Islamic understanding which tolerates diverse characteristics of its members has enabled its youths to develop their different own programs. Islamic teaching and the backgrounds of its members have been taken into consideration. The Pengajian Remaja group, labeled as the junior of PPME, ${ }^{125}$ projected to be the leaders of PPME ${ }^{126}$ developes their Islam according to youth characteristics.

\section{Dutch Speaking Group (1995): from Learning Islam to Giving Speeches on Islam}

Islamic teaching is taught to the PPME's Dutch speaking groups, found in branches in the Netherlands, except in PPME ar-Rahman in Breda in which Indonesian and Dutch languages are employed in their monthly activities. This section will explore the Dutch speaking group in the PPME of The Hague, mostly consisting of the husbands of the wives of PPME's members. Particular to the discussion is the changing roles of participants, i.e. from learning Islamic teaching to delivering speeches.

Before the program called Islamic Teaching for Dutch speaking group, the husbands of Indonesian wives of the PPME's members in The Hague attended a program called Islamic Teaching for Indonesian

121 Anonimous, “An-Nasyid Remaja@Milaadfestival.nl”, in http://www. youtube.com/watch?v=Zetx7VP3XUo\&feature $=$ related, accessed November 7, 2011.

122 Anonimous, "Islam, Jongeren en Vrede", in Rudy van der Aar, http:/ / www.iofc. nl/node/44122, accessed November 6, 2011.

${ }^{123}$ A. Naf'an Sulchan (PPME's Knowledgeable of Islam), interview, The Hague, December 11, 2011.

${ }^{124}$ See: Fathuri et al, Kiai, Musik dan Kitab Kuning, 1st Ed. (Depok: Desantara, 2009), xxix-xxxii, and see also: Qardawi, Figh al-Gina wal-Musiqi, pp. 84-94.

${ }^{125}$ Isyak, Laporan Pertanggung-Jawaban Pengurus PPME, p. 7.

${ }^{126}$ Ibid., p. 14. 
speaking group. Their attendance was due to the wish of their wives. Since then, Islamic teaching for this Indonesian speaking group was delivered in Indonesia with Dutch summary. This was the response to the request of their wives so that their husbands could understand the activities of the PPME. However, the husbands were dissatisfied with such a method that is lack of detailed information, and stimulated the emergence of the Dutch speaking group on July 2, 1995 at the musalla of al-Ittihaad belonging to the PPME, with Dutch being the working language. Since the language used is Dutch, the preacher should be a person who speak Dutch. Tjen A. Kwoei, a Dutch-Surinamese who was the chairman of PPME in Rotterdam at the end of $1980 \mathrm{~s}^{127}$ and a writer a number of articles in Dutch, ${ }^{128}$ was requested to be a teacher. ${ }^{129}$ He then delivered basic Islamic knowledge to them, ${ }^{130}$ such as Islamic pillars and pillars of faith. ${ }^{131}$

Since mid August 1996, the activities of the Dutch speaking group, consisting of not only the husbands of the Indonesian wives, but also of Islamic converts and PPME's sympathizers, have been taken a place in the mosque of al-Hikmah in The Hague, under the supervision of the Indonesian Embassy in the Netherlands. In the same year the name of al-Moekminun (the Believer), posed by one of its participants, Ludo Jongmans, was agreed. According to Asief Ishom (a leading figure of PPME), to enhance their sense of belonging to the group, they also, invited other teachers. Although Ishom's statement is not fully favoured by A. Naf'an Sulchan (another leading figure of PPME) with regard to teachers from outside, they should respect the PPME with diverse backgrounds of its members. ${ }^{132}$ The group still invites other teacher on the basis of their own arrangement. As a result, in addition to Tjen A. Kwoei, from 1996 to the year 2000 there have been other teachers invited. First of all, Moroccan Abdul Azizi has taught them tajwid, how to recite

127 See: Al-Ittihaad 19, March-April 1988, p. 13

128 See: Al-Ittihaad 10, May-June 1986, pp. 34-38.

129 Machsun, Laporan Pertanggung-Jawaban Program Kerja PPME Cabang Den Haag, Appendix 5, p. 1.

130 Mas'udi, Laporan Kegiatan-kegiatan Kepengurusan, p. 22.

131 Machsun, Laporan Pertanggung-Jawaban Program Kerja PPME Cabang Den Haag,Appendix 5, p. 1.

132 Sulchan, interview, December 11, 2011. 
the Qur'an correctly, whereas Rafiq de Vries taught the group hadith (the tradition of Prophet Muhammad) bimonthly. Secondly, pertained to the group's monthly program usually held in the forth week of the month, ${ }^{133}$ Islamic teachers coming from outsiders have delivered their speeches to the group. In 1990s they were, among others, Abdul Wahid van Bommel and Ibrahim Spalburg, ${ }^{134}$ in addition to A. Naf'an Sulchan (one of PPME's leading figure) teaching Qur'anic exegesis. ${ }^{135}$ Thirdly, in 2000s under the guidance of Ishom and Rafiq de Vries this group set up weekly and monthly programs. In association to the weekly programs, usually each Saturday afternoon, the basic teaching of Islam such as understanding of Islamic pillars and pillars of faith, and reciting short chapters of Juz 'Ammà (the thirtieth part of the Qur'an), the Prophet's Traditions and Qur'anic exegesis have been taught by the PPME's teachers. ${ }^{136}$ For the currently monthly program, in addition to a reformist Ishom, having learned Islam in al-Azhar University, ${ }^{137}$ and other Islamic preachers, a Remi Sukirman, a scholar of Islam graduating from Saudi Arabia was also involved in the monthly program. ${ }^{138}$ The participants can therefore comprehend Islam from differing preachers, ${ }^{139}$ classicalist or reformist-oriented Islam.

Having learned Islamic knowledge from Islamic teachers, ${ }^{140}$ Réné Hendriks and Ludo Jongmans earn respects, rather than religious authority in the sense of chances to deliver speeches about Islam in Dutch language. ${ }^{141}$ For instance, Réné Hendriks -one of al-Moekminun's

133 Mas'udi, Laporan Kegiatan-kegiatan Kepengurusan, p. 17.

134 G. E. Rijono Soedarso, Laporan Pertanggungjawaban Ketua PPME Cabang Den Haag Periode 1996-1997 (The Hague: PPME, December 6, 1997), Appendix 4, n.p.

135 Mas'udi, Laporan Kegiatan-kegiatan Kepengurusan, p. 22.

136 Machsun, Laporan Pertanggung-Jawaban Program Kerja PPME Cabang Den Haag, Appendix 5, pp. 1-2.

137 Ibid., Appendix 5, p. 2.

138 Remi Sukirman (an Imam of Surinamese-Javanese organization called Rukun Islam [Islamic Pillar]), interview, The Hague, February 6, 2011.

139 Hamid, "Ik Heb Merelf in Islam Gevonden", in A-Ittihaad 44, December 1995, p. 23.

140 Asif Ishom, interview, The Hague, February 12, 2012.

141 Gudrun Krämer and Sabine Schmidtke, "Introduction: Religious Authority and Religious Authorities in Muslim Societies: A Critical Review”, in Gudrun Krämer and Sabine Schmidtke, Speaking for Islam: Religious Authorities in Muslim Societies (eds.) (Leiden Boston: Brill, 2006), p. 1. 
senior participants- taught basic Islamic history to the second generation in the event called Jeugdkamp (pesantren kilat, short Islamic courses) in Rotterdam in 1996. This stimulated the board of Pengajian Remaja (Islam for Youths) to request the board of PPME at the end of 1997 to provide teachers from al-Moekminun ${ }^{142}$ - seeking for Islamic teachers speaking Dutch, ${ }^{143}$ a problem commonly faced by the youths of Muslim communities in Islamic teaching in the Netherlands. ${ }^{144}$ In 2006 he was assigned to deliver Islamic speech about the Prophet Muhammad in the commemoration of The Prophet's birthday. ${ }^{145}$ Hendriks also lectures about Islamic jurisprudence of zakat fitrah (almsgiving during Ramadan) and zakat mal (annual almsgiving of wealth) in the 2009 workshop held in The Hague and organised by International Organization for Migration (IOM) of the Netherlands discussing Indonesian people's remittance to Indonesia. Another figure called Ludo Jongmans, belonging to the Dutch speaking group, frequently talked about Islamic subjects to the group of al-Moekminun. Additionally, he acted as Islamic preacher in the marriage ceremony of Rachmawati on October 24, 2008 in the mosque of alHikmah, The Hague after the ceremony speech of marriage delivered by Sulchan. Thus, Hendriks and Yongmans become part of "Western intellectuals who truly believed in the Islamic faith, ... [and who] made great efforts to preach Islam among Western societies."146

The members of Dutch speaking group have been given chances to deliver Islamic subjects which are important not only for the PPME's Dutch speaking young generation but also for Muslim audiences outside PPME. ${ }^{147}$ This indicates that the basis and the characteristic of the PPME, emphasizing the diversity of religious backgrounds and taking European condition into account, is maintained based upon the Dutch speaking group's preferences. Due to the absence of PPME's figures knowledgeable of Islam who deliver Islamic speech, the Dutch speaking figures have opportunity to take the role.

${ }^{142}$ Machsun, Laporan Pertanggung-Jawaban Program Kerja PPME Cabang Den Haag, Appendix 5, p. 2.

143 Razaq, Neo-Muslim Intellectuals, p. 68.

144 See Dick Douwes et al, Nederlandse Moslims, p. 94.

145 Sulchan, PPME Den Haag, Appendix 5, n.p.

146 Cf.: Razaq, Neo-Muslim Intellectuals, p. 68.

147 Ibid. 


\section{Dauroh (2008): In Search of New Religious Orientation}

Since 2008 the program Dauroh ${ }^{148}$ (upgrading Islamic knowledge) has been held twice a year by the board of PPME Amsterdam, held in May and June, and December and January by inviting Indonesian preacher, Abu Haidar. ${ }^{149} \mathrm{He}$ was an alumnus of the State Institute of Islamic Studies (IAIN, later, called the State Islamic University [UIN]) Bandung, a graduate of Institute of Islam Knowledge and Arabic (LIPIA) Jakarta. ${ }^{150}$ He was a preacher for the Dauroh of PPME Amsterdam in 2008 and 2009. The following is the example of the Dauroh of 2008.

The 2008 Dauroh activities took place in the main room of the centre of PPME Amsterdam, later by mid 2010 called at-Taqwa. In this room the participants consisting of men and women separately sat on the floor listening to the preachers - after night ( $i s h \vec{a})$, dawn (subḅ) and afternoon prayers ("asr). Two meters of cloth sätir (room partition) separated the men from the women. The preacher sat together closer to men, and could see them directly. In order to link him to the place of women, the organizer of the program installed an LCD with which the women could see him through the wall while listening to his Islamic preaching. This link has certainly facilitated the women to see his gestures when he delivered his speeches. They were also provided opportunities to pose questions to him, a similar opportunity provided for the male participants.

The Dauroh of 2008 begun from 18 December 2008 to 2 January 2009, aiming at enhancing Islamic knowledge of the members' association. ${ }^{151}$ Therefore, subjects ranging from Islamic faith to woman with specific books were discussed in the Dauroh program. For its everyday activities, a book entitled Arba'in Nawainn (Forty Traditions of the Prophet) of Imam Nawawi was read. This session commenced from 15:00

148 Dauroh [Dawratun] literally means course of instruction. Hans Wehr, $A$ Dictionary of Modern Written Arabic, ed. J. Milton Cowan, 3rd ed. (Wiesbaden: Spoken Language Service Inc., 1976), p. 299. In PPME Amsterdam it is used to name its program of improving Islamic knowledge for its members.

149 A. Aziz Balbaid, Jadwal Dauroh Amsterdam via e-mail, (Amsterdam: PPME, December 11, 2009), n.p., see also: Euromoslim, June 1, 2011, n.p., and Abu Haedar, interview, Bandung, April 11, 2009.

150 Ibid.

151 Balbaid, interview via e-mail, December 11, 2009. 
to 16:00. Then, a theme on Islamic faith, "Toward the Comprehension of True Islamic Faith" used Sharḅu Thaläthati al-Usül (the Commentary on Three Principles) written by Muhammad ibn Șalih al-'Uthaimin. This topic was delivered from 19:00 to 21:00. Another book entitled "Riyadu al-Sälibin (the Garden of Good People)" of Imam Nawawi was also discussed from 07:00-08:00 (after dawn prayers). ${ }^{152}$ Reading al-Wasäilu al-Mufídati lil-Hayäti al-Sa 'ída (Effective Media for Achieving Happiness) of Qasim 'Abd al-Rahman was held each Sunday from 13:00 to 16:00. Islamic sermon for women was held each Wednesday from 13:00 to 16:00. For example, a book entitled Wäjibätu al-Mar'ati al-Muslimati fi Naģrati al-Qur'an wal-'Sunnah (Obligations for Female Muslim according to the Qur'an and the Tradition of the Prophet Muhammad) of Ummu 'Amr was read. ${ }^{153}$ Thus, within two weeks the preacher delivered Islamic courses to the participants of the Dauroh.

It is worth mentioning that despite the fact that various topics on Islam were mostly delivered during the Dauroh, Islamic faith has drawn much more attention of the program's organizer. In addition to be part of its every day program, the subject on Islamic faith was scheduled from 19:00 to 21:00. This is in line with the theme of the Dauroh of 2008, i.e. Menuju Pemahaman Aqidah Islam yang Benar (Toward an Understanding of True Islamic Faith). ${ }^{154}$ Therefore, the theme relates to the breaking of PPME Amsterdam's members into two groups - PPME Amsterdam and PPME al-Ikhlash - by mid 2005 due to their different comprehension on the aqida (faith) subject pertained to the performing al-istighathah (appeal to God's aid). ${ }^{155}$

Istighathah is prayers for asking God's protection, ${ }^{156}$ and God's aid in solving worldly life's, for instance, as the congregation of PPME al-Ikhlash undergoing difficulties in their life. ${ }^{157}$ Istighathah is, thus, the

${ }^{152}$ Humas, Meniju Pemahaman Aqidah yang Benar (Amsterdam: PPME, December 6, 2009), n.p., and Abu Haedar, interview, April 11, 2009.

153 Ibid.

154 Balbaid, Jadwal Dauroh Amsterdam (Amsterdam: PPME, December 6, 2009), n.p., and see also: Euromoslim, June 1, 2011, n.p.

155 Machsun, Laporan Pertanggung-Jawaban Program Kerja PPME Cabang Den Haag, 7.

156 See: Martin van Bruinessen, Kitab Kuning: Pesantren dan Tarekat (Tradisi-tradisi Islam di Indonesia) (Bandung: Mizan, 1995), p. 277.

157 See: Lukens-Bull, A Peaceful Jihad, pp. 4-5. 
recitation of prayers that is long and more various than the tablilan (part of the istighäthah). It also includes reciting God's names (Asmāal-Husnä). In PPME's activities yasinan and tablilan have been performed as the introductory part of the istighathah. All the prayers were been recited like the way of reciting prayers of Qādiriyya sufism tradition. ${ }^{158}$

Instead of performing the istighathah (including tablilan and yasinan) the members of the board of PPME Amsterdam preferred Dauroh. They raised their objection against istighäthah in its new building which was purchased at the end of 2004, on Ekingenstraat. ${ }^{159}$ Such an objection is in line with the viewpoint of Jawaz (one inspiring the emergence of Indonesian modern salafi movement). Referring to a book entiled Irshäd al-Bariyya (The Guidance of Creature) by Abū 'Abd al-Salām Hasan ibn Qasim al-Hasani, he argues that salafi does not gather in performing bid'a (innovation). ${ }^{160}$ Similarly, the PPME Amsterdam's members argue that istighathah would lead to shirk (polytheism) and was not based upon Islamic teaching (bid'a, innovation). ${ }^{161}$ This is evident among the members of PPME Amsterdam. The PPME al-Ikhlash disagree with this. For instance, Hasanah Iman (a pseudonym), who frequently attended the istighäthah of Majlis Dzikir (a gathering for remembering God under the organization of people of PPME al-Ikhlash), said:

All good deeds are allowed to do even though there is no Prophet Tradition dealing with them as far as they are not against Sharì'a (Islamic Law)... However, they [who are currently members of PPME Amsterdam and anti Majlis Dzikir] have regarded us [who are regularly reciting istighäthah] as polytheists due to the istighathah. Remember and be careful, there is a Prophet Tradition asserting that a Muslim who claims another [Muslim] as a polytheist is a poliytheist! ... [As a consequence], if you [anti masjlis dzikir] do not want recite the dzikr [istighäthah] together with us because your ulama prohibit it, we [the participants of majlis dzikir] have no objection and won't judge you as people going astray because it is your business. Do not force and oblige Muslims all over the world

158 See: Martin van Bruinessen, Kitab Kuning: Pesantren dan Tarekat. 1st Ed., Transl. By Farid Wajidi and Rika Iffati (Yogyakarta: Gading Pablishing, 2012), 266.

159 A. Aziz Balbaid (an Advisor of PPME Amsterdam), interview, Amsterdam, July 28, 2008.

${ }^{160}$ Yazid bin Abdul Qadir Jawas, Mulia dengan Manhaj Salaf (Bogor: Pustaka at-Taqwa, 2009), p. 253.

161 Astin, interview, December10, 2009, and Balbaid, interview, July 28, 2008. 
not to recite such a deed [reciting istighäthah]! Do not judge them [the Muslims] as infidels, people going astray and people doing wrong due to such a deed. ... Your imam himself, al-Bānī, asserted in his book entitled Tamamu al-Minnah: a weak Prophet Tradition [ [. aditsun da îfun] will reach a higher level, i.e becoming a hadīth ḥasan (a good Prophet Tradition). Istighäthah is allowed. ${ }^{162}$

Understanding the istighathah and the emergence of emotional responses of the PPME al-Ikhlash Amsterdam has driven the PPME Amsterdam's board to select books of Islamic faith used as references for the participants of the Dauroh. The PPME was founded on the basis of the diversity of religious backgrounds of the founders - classicalists, reformist, and new converts who become the backbone of the PPME. Such diversity has been evident among the members of the PPME in The Hague, Rotterdam, Amsterdam, and Breda-Tilburg. However, the classicalist group (who are in favor of the establishment of the PPME al-Ikhlash) is no longer found among the PPME Amsterdam since its disintegration. Despite the fact that there is an objection for the current religious orientation among the PPME Amsterdam's members, ${ }^{163}$ salafi reformist religious orientation is the preference for the PPME Amsterdam's board. ${ }^{164}$ The presence of Abu Haedar, a salafi preacher ${ }^{165}$ in the 2008-2009 Dauroh is a prominent proof. Secondly, as a result of inviting the salafi preacher, references used in the Daurob program are in line with the salafi preferences. For instance, Sharbu Tsalstsati al-Usüli (The Commentary on Three Principles), written by a well-know figure among salafi group, Muhammad ibn Shalih al-'Utsaimin, ${ }^{166}$ has been used in the program for the subject of Islamic faith. ${ }^{167}$ The Indonesian translation of this Arabic book is provided so that the program's participants can buy and read the translated book. This book informs, among others, the

162 A letter of Hasanah Iman sent to the members of PPMEAmsterdam and of PPME al-Ikhlash on July 27, 2005, pp. 2-5.

${ }^{163}$ Frans Maasdam (a member of Dutch speaking group of PPME Amsterdam), interview, Yogyakarta, August 23, 2011.

164 A. A. Balbaid, interview, The Hague, April 7, 2011.

165 See: Anonymous, "Abu Haedar.Net: Menebar Kesejukkan dan Memupuk Kelemahlembutan", in abuhaedar,net, accessed June 9, 2013.

166 Samir Amghar, "Salafism and Radicalization of European Muslims", in Samir Amghar (eds.), European Islam (Brussels: CEPS, 2007), p. 43.

167 Abu Haedar, interview, April 11, 2009. 
danger of polytheism, i.e. the great polytheism bringing about infidelity, and the small one which does not lead to the infidelity. Additionally, Istighäthah are also avoided. ${ }^{168}$

Related to the istighathah, the above mentioned book reveals that it is classified into four kinds. There is prayer for Allah's aid directly, from dead and living people incapable of providing assistance, and from living people capable of providing assistance, and from living people incapable of providing assistance. The second and fourth kinds are not allowed to conduct. The former will lead to polytheism (shirk) whereas the second is blasphemy to religion. ${ }^{169}$ The classification clearly shows that istighathah, - not including the congregation of PPME Amsterdam - have appealed for Allah's aid by mentioning names of ulama, such as 'Abdul Qādir al-Jīlāni (a sufi) won't be accommodated in the activities of the PPME Amsterdam, after consolidating their new religious orientation with "the correction of belief and religious activities", ${ }^{170}$ This religious orientation is called, by Samir Amghar as "Predicative Salafi". ${ }^{171}$

To conclude, the Dauroh program, as the vehicle for the boards of the PPME Amsterdam to upgrade the comprehension of its members on Islam has served as means to shape salafi religious orientation. This formation of new religious orientation does not oppose the characteristics of the PPME emphasizing the diversity of religious backgrounds among its members. Thus, the new religious orientation may actually extend the PPME's identity when the diversity still finds its space among its members --exercising the basis of the PPME without ignoring their socio-religious backgrounds. Disintegration among the members of the PPME in Amsterdam indicates the opposite condition.

168 Zaenal Abidin Syamsuddin and Ainul Haris Arifin, Ulasan Tuntas tentang Tiga Prinsip Pokok: Siapa Rabbmu? Apa Agamamu? Siapa Nabimu?, (Jakarta: Darul Haq, 1999), pp. 52-55 and 95-97.

169 Ibid.

170 Samir Amghar, "Salafism and Radicalization of European Muslims", in Amghar (ed.), European Islam (Brussels: CEPS, 2007), pp. 42-45; Jawas, Mulia dengan Manhaj Salaf, pp. 252-253.

${ }^{171}$ Samir Amghar, "Salafism and Radicalization of European Muslims", pp. $42-45$. 


\section{Through the Oeuvres available in al-Ittibaad (1985) and Euromoslem (1992)}

The publication of bulletins is part of PPME's activities in the Netherlands since early $1972 .{ }^{172}$ There are six bulletins known among the association's congregations. For instance, al-Falah (Victory) issued from 1972 to the late 1970s, ${ }^{173}$ aI-Ittibaad (Integration) published from 1985 to the late 1990s, ${ }^{174}$ and Iqra' (Read!) issued from 1996 to the late $1990 \mathrm{~s},{ }^{175}$ all of which are PPME's bulletins under the organization of the central office. Meanwhile, its branches in the Netherlands have also issued other publications such as Euromoslem (Muslim in Europe) published from $1993^{176}$ to the present under the organization of PPME Amsterdam, Zikra (Remembrance) issued from 1995 to the late 1990s under the organization of PPME in The Hague, ${ }^{177}$ and PPME Bulletin Afdeling (Branch) Rotterdam from early 1999 to early 2000. ${ }^{178}$ Due to the available bulletins circulated among the PPME's members, Islamic backgrounds of the writers of al-Ittihaad and Euromoslem will be discussed in this section.

Al-Ittihaad has been published more than ten years (from 1985 to the late 1990s). This bulletin does not only deal with important events but also thoughts of adults, youths and sympathizers of the PPME. This is because since its publication al-Ittihaad has served as the medium for the PPME. ${ }^{179}$ In addition, the bulletin also served as means of PPME's

172 See Dewan Pimpinan Pusat, Laporan DPP PPME pada Musyawarah Umum I dari Tanggal 25-26 Agustus 1973 (The Hague: PPME, n. y), n.p.. In early 1972 Muslims firstly issued their newspaper in West Europe. Issabelle Rigoni, "Access to Media for European Muslims”, in Amghar (ed.), European Islam (Brussels: CEPS, 2007), p. 118.

173 Sjaiful A. Rangkuti, Laporan Pertanggung Jawab Mandataris: Musyawarah Umum PPME/Ketua Umum DPP PPME Periode 19879-1982 (Achen: PPME, November 12-14, 1982), 11, and see also: Dewan Pimpinan Pusat, Laporan DPP PPME pada Musyawarah Umum I dari Tanggal 25-26 Agustus 1973 (The Hague: PPME, 1973), n.p.

174 A. Naf'an Sulchan, Laporan Pertanggung-Jawaban Program Kerja PPME Wilayah Nederland Periode 1997-1999 (The Hague: PPME, 1999), p. 7.

175 See: Iqra' 3, January-February 1998, 1.

176 See: Euromoslem 22, July 1995, n.p.

177 See: Zikra, May 1997, n. p.

178 See Bulletin Afdeling Rotterdam 6, November 1999, n. p. and see also: PPME Rotterdam 1, Year 2, March 1 2007, n.p.

179 Al-Ittihaad 10, May-June 1986, 2. Al-Ittihaad often informs the socio-cultural events of the PPME and other Islamic associations in the Netherlands. For instance, 
$d a^{\prime} w a^{180}$ in the sense of providing Islam knowledge ${ }^{181}$ written by authors

the bulletin reported: the success of the PPME's board in purchasing the place of worship, called, the musalla of al-Ittihad in The Hague; prayers of 'id al-fitri and 'id al$a d h \bar{a}$; the schedule of halal-bihalal (apologizing one another); and the commemoration of the Prophet Muhammad's birth along with the inauguration of the purchase of al-Hikmah, an Indonesian mosque in The Hague. the bulletin also lovers the news about the Surinamese-Javanese association in The Hague, called, Rukun Islam (Islamic Pillar) requiring financial aid for the purchase of a building for musalla in the city; the number of the students of al-Ghazali School - an Islamic school in Rotterdam; the inauguration of the establishment of a Surinamese-Javanese foundation called Stichting Rachmatullah Islam (SRI, Islamic Foundation) in Noord-Brabant; and the Stichting Haagshce Islamitisch Platform (SHIP) organizing a Moslim Vrouwendag (Muslim Women Day) in Clubhuis Boshout - The Hague. See: Al-Ittihaad, Nomor Khusus, 1985, 11, Al-Ittihaad 10, May-June 1986, 26-27, Azhari Kasim, Memorandum Akbir Jabatan Ketua Pengurus Sementara Masjid al-Hikmah (The Hague, PPME, July 31, 1997), 1-9, Al-Ittihaad 25, July-August 1989, 56 and 59, and Al-Ittibaad 44, December 1995, 31. In addition to the aforementioned news, issues on Indonesia were reported. These can be found in the bulletin of 1980s and 1990s. In 1985 the inauguration of Musalla of al-Ittihaad on July 13, 1985 in The Hague was reported. In this event the chairperson of the PPME addressed the Indonesian tradition of Halal Bibalal, an event for asking for apology among its participants. See: PPME Wilayah Nederland, "Sambutan Ketua PPME pada Hari Halal Bihalal dan Peresmian Muṣalla al-Ittihaad 23 Syawal 1405 H/13 Juli 1985", in Al-Ittihaad Nomor Khusus, July 13, 1985, 2-3. Then, in al-Ittihaad's edition of November-January 1993-1994 Indonesia as home land can be found from an article entitled "Indonesiaku" (My Indonesia). This article presents the picture of the home land based on the observation and the feeling of its writer describing Indonesia from the writer's perspectives. The rural place was conceptualized as the comfortable in the sense of environment free from air pollution and natural landscape whereas the urban was regarded as uncomfortable environment area. Apart from the viewpoints that are subjective, the author aimed at sharing information to the bulletin's Indonesian readers on their home country. Then, in its edition of November 1996 an article entitled "Kemerdekaan Indonesia Berkat Rahmat Allah Swt" (Indonesian Independence due to God's Blessing) provided information on Indonesian independence. The significance of this article was its emphasis on the fact that the independence was not gift of Japan but the struggle of Indonesian people with God's blessing. See: al-Ittihaad, NovemberJanuary 1993-1994, pp. 24, 27, 30 and 31. 1980s and 1990s show that PPME, which pays attention to the needs of its members in Europe especially in the Netherlands, did not led the PPME's bulletin's organizers to forget the socio-cultural and political developments in Indonesia.

180 Al-Ittihaad 10, May - June 1986, p. 2.

181 There are two definitions of $D a^{\text {w wa }}$, i.e. firstly, delivering Islamic teaching and secondly, inviting audience to repent. Thohir Luth, M. Natsir: Dakwah dan Pemikirannya (Jakarta: Gema Insani, 1999), p. 80. 
with diverse Islamic backgrounds.

In 1980s there were four articles of al-Ittihaad dealing with Islamic knowledge. In its special edition July 13, 1985 A. Hambali Maksum, having a historical connection to the Nahdlatul Ulama, discussed the significance of attending Indonesian tradition called halal-bibalal (asking for apology among its participants) as vehicle for performing Islamic teaching of sillatu al-rabim (kinship relationship). He argued that the tradition is not harmful for Muslims because it is not part of pure worship (ibadatu mahda). To support the tradition, he quoted a hadith: "You should know more than me [The Prophet] about your mundane affairs". ${ }^{182}$ Secondly, al-Ittihaad of March-April 1988 covers that eating foods in the house of people in condolence is considered sinful even though there is no exact Islamic evidence (dali $)$ which directly prohibited it. This information was quoted from a reformist-oriented magazine called Panji Masyarakat (the Banner of Society). ${ }^{183}$ Then, in al-Ittihaad 25, July-August 1989, A. Syafi'i Ma'arif having connection to Muhammadiyah, an Indonesian modernist-Islamic organization, discusses the significance of establishing bridges leading to harmonize the Muhammadiyah and Nahdlatul Ulama by inviting their youths to support each other (kompak labir batin). ${ }^{184}$ Last but not least, in another edition of al-Ittihaad July-August 1989 M. Natsir, having involved himself in the activity of Persatuan Islam (Persis, the Unity of Islam) and the chairperson of Dewan Dakwah Islam Indonesia (DDII, Council of Indonesian Islamic Propagation), ${ }^{185}$ emphasizes the significance of tolerance among Indonesian religious adherents in creating harmony (kerukunan) in the Indonesian New Order. He claimed that endeavors of Muslims in Indonesian parliament for legislation of Law of Marriage and Religious Court faced resistance from their Christian and Catholic

182 A. Hambali Maksum, "Sambutan Ketua PPME pada Hari Halal Bihalal dan Persemian Muṣalla 'al-Ittihaad'23 Syawal 1405H / 13 Juli 1985 M”, in Al-Ittihaad, Special Edition, July 13, 1985, pp. 2-4.

183 Panji Masyarakat 568, March 1-10, 1988, n. p., and see also Anonymous, "Makan-makan di Rumah Ahli Mayyit", in Al-Ittihaad 19, March-April 1988, p. 21.

184 A. Syafi'i Ma'arif, “Mubammadiyah-NU: Memupus Trauma Masa Lalu”, in AlIttihaad 25, July-August 1989, 15-16.

185 See: George McT. Kahin,"In Memoriam: Mohammad Ntasir (1903-1997)", Indonesia 56, October 1993, pp. 180 and 185. 
colleagues. ${ }^{186}$ It is worth mentioning that in contrast to other articles of al-Ittihaad dealing with other subjects written in Dutch or English, all Islamic subjects discussed above were written in Indonesian, a language which Indonesian reformist do not commonly use for their writings. ${ }^{187}$ Authors have connections to diverse religious organizations in Indonesia. In this way, the readers are allowed to acquire Islamic knowledge from different sources of religious orientations. ${ }^{188}$ This tendency of $1980 \mathrm{~s}$ remains evident in al-Ittihaad of 1990s.

In al-Ittihaad of December 1995 M. Chaeron - the former journalist of Masyumi's newspaper called $A b a d i^{189}$ - posed an idea of the integration of the curriculum of PPME's religious education for children with that of Indonesian Islamic formal education. This will provide the children of Sekolah Indonesian Nederland (SIN, Indonesian School in the Netherlands) enough religious education. This was suggested in one day seminar held on August 26, 1995 at the SIN Kiat Mencari Pendekatan Baru Pendidikan Agama di Era Globalisasi (Keys to Search for New Approaches in Religious Education in the Era of Globalization). ${ }^{190}$ Secondly, in al-Ittibaad of the edition of November 1996, K.H. Zainuddin, M.Z., ${ }^{191}$ a graduate of the State Institute of Islamic Studies (IAIN, later called, Universitas Islam Negeri [UIN, Islamic State University]) Jakarta and the "preacher of a million of umma [audiences]", ${ }^{192}$ writes about the importance for

186 M. Natsir, "Tanpa Toleransi Tak-Kan Ada Krukunan”, in Al-Ittihaad, July-August 1989, pp. 10-14.

187 Bruinessen, Kitab Kuning, pp. 19-20.

188 Cf. Jajat Burhanudin, "Traditional Islam and Modernity: Some Notes on the Changing Role of the Ulama in Early Twentieth Indonesia", in Azyumardi Azra et al, Varieties of Religious Authority: Changes and Challenges in 20th Century Indonesian Islam (Singapore: ISEAS, 2010), p. 55.

189 Abadi serves as the medium of masyumi's voice especially NU left Masyumi due to its political orientation not parallel to that of Masyumi. See Tim Epi/Bai, "A dari Ensiklopedi Pers Indonesia (EPI)", in http://www.pwi.or.id/index.php/ presspediapwi/787-a-dari-ensiklopedi-pers-indonesia-epi, accessed June 1, 2013.

190 Hasan Basri, "Catatan dari Seminar Sehari: Jihad PPME Menangkal Arus Distorsi Nilai di Era Globalisasi (Report)", in Al-Ittihaad 44, December 1995, 21.

191 See: Stevy Maradone, "Zaenuddin M. Z. Sejak Kecil Bakat Dakwahnya Sudah Terlibat', in http://www.republika.co.id/berita/nasional/umum/11/07/05/lnueenzainuddin-mz-sejak-kecil-bakat-dakwahnya-sudah-terlihat, accessed December 29, 2011.

192 Zainuddin M. Z. also involved himself in Partai Persatuan Pembangunan (PPP) from 1977 to 1982 because of the invitation of his Islamic teacher Idham Khalid 
the young generation of Indonesian Muslims in the Netherlands to keep Indonesian personalities and identity while conducting their daily activities. Additionally, it is necessary to provide religious education especially through examples of their parents; called Mecca-oriented heart (berbati mekkah). ${ }^{193}$ Lastly, in the same edition, Abdurrahman Wahid, a leader of Nahdlatul Ulama (NU), discusses Islamic ethics on the basis of sufism and fiqh (Islamic jurisprudence). Ethic is emphasized as 'ibädatun mahda (worship) whereas the latter is legal-formalistic ethics. ${ }^{194}$ This shows the characteristics of the bulletin in the period of 1990s, i.e. the use of Indonesian language with authors having differing religious backgrounds. ${ }^{195}$ Nevertheless, in 1980s and 1990s the bulletin show consistency of the editors in providing space for the authors owning differing religious backgrounds. This consistency is in line with the characteristics of PPME's policy. This signifies that the bulletin has serves not only as the provider of religious knowledge but also as the media accommodating differing backbones of the association in religious domain, but al-Ittibaad is no longer solid in the following periods.

Now, we come to another bulletin issued by the PPME's branch in Amsterdam. As with the function of al-Ittihaad, Euromoslem is published no less than nineteen years (from 1992 to 2011). It serves as the vehicle of PPME's da'wa and information. ${ }^{196}$ Paper-based bulletin is issued from

who was a former chairman of Nahdlatul Ulama (NU). See: "Referensi Biografi Tokoh dan Public Figure", in http://biografi.rumus.web.id/biografi-k-h-zainuddin-m-z/, accessed June 1, 2013.

${ }^{193}$ K. H. Zainuddin, M.Z., "Bahaya Orientalis, Islam Fundamentalis, Kader Dakwah dan Emansipasi Wanita: Sebuah Solusi dan Strategi (an Interview by Emma Rodini), in Al-Ittihaad Special Edition, November 1996, pp. 17-18, and 23.

194 Abdurrahman Wahid, "Spiritualitas Islam dalam Masyarakat Modern", in Al-Ittihaad Special Edition, November 1996, pp. 28-29, and 35.

195 See: Burhanudin, "Traditional Islam and Modernity: Some Notes on the Changing Role of the Ulama in Early Twentieth Indonesia", in Azra et al, Varieties of Religious Authority, p. 55

196 The contents of Euromoslem are mostly similar to those of al-Ittihaad. As a consequence, information on the coming events of PPME such as the agenda of halal bibalal, sportsdag (sport day), and the prayers of id al-fitri and id al-adha are reported. In addition to the events, important events in association to Indonesia - most of them pertained to the celebration of Indonesian independence - are reported. For instance, in the Euromoslem of July 1995 information on the sport championship to commemorate Indonesian independence was mentioned. Through this edition, the board of PPME 
$1992^{197}$ to 2003. Since 2005 the bulletin is issued in a digital form, and named Euromuslim. As the da'wa means, through Euromoslem Islamic knowledge has been circulated in the congregation of PPME Amsterdam.

Prior to 2005, Islamic discourses written in Euromoslem come from authors with diverse Islamic backgrounds. The writings of both nonsalafi and salafi authors ${ }^{198}$ are given the same space. For instance, Maksum with connection to NU discusses the Islamic Law on the aurat ['awra]. He stateds that there are two mainstreams, i.e. obligatory and not obligatory for covering all parts of the body during five times prayers. According to him, ulamas in favour of the obligatry are textualists, whereas those holding the second one are contextualist. ${ }^{199}$ Muhammad Taufiq, a member of the board of Ikatan Cendekiawan Muslim Indonesia Organisasi Wilayah (Orwil, Regional Organization) of Surabaya, wrote in Euromoslem of June 1997 on migration (bijra) from the wrong (bätil) to the true (baq) by leaving bad traditions for the sake of implementing shari $a$ (Islamic Law) ${ }^{200}$ Masjfuk Zuhdi, a lecturer of the State Institute of Islamic Studies (IAIN) Sunan Ampel of Surabaya wrote the issue of body transplantation in Euromoslem of May 1998. He cites Qur'anic verses and Islamic legal theories of non salafi ulama. ${ }^{201}$ In the edition of July and August 1999 presented the writing of A. M. Fatwa, an Indonesian reformist-oriented

Amsterdam invited its congregation to participate. See: Euromoslem 22, July 1995, 8. Then, in the Euromoslem edition of September-October 2000 the readers were invited to pray for God in order to bestow His Blessing (Rahmat), Easiness and Patience on Indonesian leaders to conduct their tasks mandated by their people. See: Euromuslim 74, September-October 2000, 12. This is the last edition of Euromuslem issuing such information. Hence, these issues could no longer be found in its edition of July-August 2003. See: Euromoslim 91, July-August 2003, 13.

197 Euromuslem 8, May 1994, 1, and see also: Euromuslem 22, July 1995. n.p.

198 Salafi is person whose faith (aqida), law (sharì $a$ ), behavior (akbläq), and invitation ( $\left.d a^{\prime} w a\right)$ rely on the way (manhaj) of Salaf, i.e. the companions of The Prophet Muhammad, their followers, and the followers of the followers of the companions. See: Yazid bin Abdul Qadir Jawas, Mulia dengan Manhaj Salaf (Bogor: Pustaka at-Taqwa, 2009), 22-23.

199 A. Hambali Maksum, "Hukum tentang Aurat Wanita, in Euromoslem 16, January 1995, pp. 5-7.

200 Muhammad Tufiq, "Hijrah dari Kesalahan menuju Kebenaran", in Euromoslem, June 1997, pp. 4-5.

201 Masjfuk Zuhdi, "Pencangkokan Organ Tubuh", in Euromoslem, May 1998, pp. 8-11. 
Muslim, on the obligation of performing da'wa. He argues that to defend and sustain the life and the common good (kemaslahatan) of society, every individual serves as a primary agent of Islam and God. ${ }^{202}$ The writings of these authors with Islamic backgrounds other than salafi coloured the space of Euromoslem. But, the writings of salafi authors can also be found. The following is an example.

Books, written by International salafi authors are used as references of the following Indonesian salafi authors: Muhammad ibn Shalih al-Utsaimin (a student of 'Abdu al-'Aziz 'Abdu Allāh ibn Bāz), ${ }^{203}$ Ibn Taymiyya, al-Bani and Ibn Qayyim who have inspired the emergence of da'wa salafi movement. ${ }^{204}$ Referring to a book entitled Fathu Rabbi al-Bariyya (Introduction to God of Creature) by al-Utsaimin in which he advocates manbaj (method of) salafi does not accept any interpretation (ta'wil), Muhammad Afifuddin in Euromoslem of April 1998 believes in the existence of Allah's attributes. ${ }^{205}$ In the same edition Ahmad Faiz Asifudin who is one of the Indonesian salafi leaders ${ }^{206}$ discusses al-firqatu al-näjiya (the rescued group) in reference to book al-Aqida al-Wäsitizya (the Mediating Faith) of Ibn Taymiyya. According to Asifudin, belief in Allah has to do with belief in His attributes - rationality has no right to interpret them; but based on revelation (Qur'anic evidence). ${ }^{207}$ Subsequently, Khalid al-Rasyid wrote sillatu al-raḩim (kinship relationship) presented in Euromoslem 82, January-February 2002. In this writing, al-Rasyid mentions not only on Qur'anic verses and the Prophet's Traditions, but also refers to central figures of salafi-oriented Muslims and their books, such as, al-Bani’s works, Șähib al-Jāmi' (the Holder of Society) and Silsilatu Șạīha

202 A. M. Fatwa, "Kewajiban Berdakwah", in Euromoslem 67, July-August 1999, p. 11.

203 See: Syamsuddin and Arifin, Ulasan Tuntas tentang Tiga Prinsip Pokok, 4.

204 Noorhaidi Hasan, "From Apolitical Quietism to Jihadist Activism: 'Salafis', Political Mobilization and Drama of Jihad in Indonesia", in Azra et al, Varieties of Religious Authority, pp. 140 and 143.

${ }^{205}$ Muhammad Afifuddin, "Penetapan Sifat Mababbah bagi Allah", in Euromoslem 55, April 1998, pp. $2-3$.

${ }^{206}$ Hasan, "From Apolitical Quitism to Jihadist Activism", in Azra et al, Varieties of Religious Authority, p. 143.

207 Aḥmad Faiz Saifullah, "Bagaimana Membangun Imam yang Benar", in Euromoslem, September-Oktober 2000, 2pp. -3. 
(Valid Chain). ${ }^{208} \mathrm{He}$ argues that sillatu al-rahim should be established within family, neighborhood and society in order to be able to establish social ties. ${ }^{209}$ Then, between July and August 2003 Euromoslem presented Ibn Qayyim al-Jauziyyah's work on the keeping away of Muslim from committing zinā (adultery) by controlling his or her words, and holding his or her commitment to avoid zina. The author also informs about the bad impacts of zina on the person and family, and the baby born out of zina. ${ }^{210}$ Since the late 1990s reformist-oriented works, among which are salafi's works, have dominated the contents of Euromoslem.

Disunity among the congregation of the PPME Amsterdam in 2005 resulted in the absence of the printed versions of Euromoslem and led to the emergence of its digital-form ${ }^{211}$ such as "euromoslem@, ppme-amsterdam.org, muslimnl@yahoogroups.com, and media@ euromoslim.org". ${ }^{212}$ Through these emails, the domination of writings of salafi-reformist authors becomes more evident in Euromoslem, serving as the vehicle for $d a^{\prime} w a{ }^{213}$ For instance, the significance of Islamic knowledge became the topic of Euromuslim 452, January 2009. ${ }^{214}$ The work of Muhammad Abdul Tuasikal (the leader of salafi Pesantren

${ }^{208}$ Hasan, "From Apolitical Quitism to Jihadist Activism", in Azra et al, Varieties of Religious Authority, p. 140, and see also: Stéphane Lacroix, "Al-Albani's Revolutionary Approach to Hadith", in ISIM Review 21: Migrants, Minoroties and the Mainstream, Spring 2008, pp. 6-7. pp. 2-11.

209 Khalid ar-Rasyid, "Silaturahim”, in Euromoslem 82, January-February 2002,

${ }^{210}$ Ibn Qayyim al-Jauziyya, "Jangan Dekati Zina", in Euromoslem 91, July-August, 2003, pp. 7-12.

211 Siti Fatimah (a Chairperson of Educational Division of PPME Amsterdam), interview by phone, December 23, 2011.

${ }^{212}$ Issabelle Rigoni, "Access to Media for European Muslims", in Amghar (ed.), European Islam, pp. 118-119.

${ }^{213}$ Information on events from Indonesian government or Indonesian Embassy in the Netherlands has fallen outside its contents. Then, information on coming events has been sent to PPME Amsterdam's members and its sympathizers in one of the addresses of aforementioned e-mails. Each address has alternatively been accustomed to use. When the coming events such as the schedule of "id al-adha $\bar{a}$ prayer of 2009, and of "Dauroh Ilmiyyah Islam (Upgrading Islamic Knowledge)" of 2009-2010 with Abu Haidar were informed, for instance, through media@euromoslim.org, articles on Islam were sent through the other address of the e-mails. The contents of the current digital Euromoslem have mostly weekly been distributed to its members and sympathizers.

214 Euromoslem 460, Year 11, November 20, 2009, n.p. 
Darushsholihin, Yogyakarta) ${ }^{215}$ on Islamic faith became the theme of Euromuslim 447, 11 September 2009. ${ }^{216}$ An article on the right to be imam for prayers by Abu Asma Kholid Syamhudi's writing was the topic of Euromuslim 460, January 2010. This writing refers to a salafi-oriented magazine called As-Sunnah (the Prophet Tradition), ${ }^{217}$ edition 5, year X, 2006. ${ }^{218}$ The etiquette to treat parents both Muslim and non-Muslim was the topic of Euromoslim 503, December 3, 2010. ${ }^{219}$ Ten principles for seeking beneficial knowledge by 'Abdullah ibn Shalfiq al-Zafiri, is the topic of Euromuslim 516, March 4, 2011. ${ }^{220}$ Another article about how to pay fidya (fine) refers to the idea a reformist Muhammad Abduh. Presented in Ramadan edition of Euromuslim on 16 August 2011, Abduh explains a Muslim who is no longer capable of performing the fasting in Ramadan, due to his/her old age or sickness, is permitted to pay fidya to the poor according to the number of days which he/she missed by giving $1.5 \mathrm{~kg}$ rice per day. ${ }^{221}$ Thus, after 2005, there is a tendency of stressing a single stream of religious sources, i.e. reformist salafi-oriented authors, seen in the contents of Euromuslim - endorsed by PPME Amsterdam. Apparently, their diverse socio-cultural and religious backgrounds are neglected. ${ }^{222}$

To sum up, Islamic discourses, developed in al-Ittihaad and Euromoslem (or Euromoslim) and becoming written Islamic old edition of sources for the PPME's members and sympathizers, show different

215 Muhammad Abduh Tuasikal, "About Me”, in http://rumaysho.com/ about-me.html, accessed December 29, 2011.

216 Euromuslim 447, Year 11, September 11, 2009, n.p.

217 Ahmad Faiz Asifuddin (one of Indonesian salafi leaders) has been the chief executive of the magazine of As-Sunnah since 1996. See http://majalah-assunnah. com/edisi/07xv/, accessed December 29, 2011. Asifuddin (Solo) is one of driving people of Indonesian modern salafi movement such as Yazid Abdul Qadir Jawwaz (Bogor), Ja'far Umar Abu Thalib (Yogykarta), Muhammad Umar al-Sewed (Solo), Abu Nida' (Yogyakarta), and Abdul Hakim Abdat (Jakarta). They all are the editors of the al-Sunnah (the Prophet Tradition) Magazine. Moh. Salim aldjufri, Wabdah Islamiyyah di Gorontalo, 1st Ed. (Jakarta: Kemenag RI, 2011), p. 72.

218 Euromuslim 460, Year 11, January 15, 2010.

219 Euromuslim 515, Year 12, December 3, 2011.

220 Euromuslim, March 4, 2011.

221 Euromuslim, Ramadan Edition, August 16, 2011.

222 Cf. Issabelle Rigoni, “Access to Media for European Muslims”, in Amghar (ed.), European Islam, pp. 118-119. 
religious orientation. In the old edition of bulletin traditionalist, classicalist, and reformist were accommodated, featuring diverse religious orientation. There was no driving force to lead the organisation a single religious orientation. However, in the later issue reformist works became dominant. As a result, Islamic discourses other than the reformist religious orientation has almost no room. Conflict in the PPME Amsterdam's congregation by mid-2005 drives the feature of the current bulletin into a single salafi religious orientation. In short, Salafi works dominates Islamic discourses of the current Euromoslem (Euromuslim).

\section{Conclusion}

Having dealt with religious practices developed by the PPME in the Netherlands and religious discourses presented in the two bulletins al-Ittihad and euromoslem there are three concluding remarks. PPME's Central board of the Nehterlands has freed its branches to shape their religious identities as far as the formation does not oppose its fundamental principles and characteristics. However in the PPME branch Amsterdam, the conservative salafi orientation has recently dominated the Islamic atmosphere, when adjustments to both Indonesian religious development and Dutch conditions are made in the formation of religious identities, negotiation is indispensable. This signifies that a single religious preference and the repudiation of other religious preferences will not be succesful due to the diversity of the PPME members' religious backgrounds and characteristics. Indeed, since the PPME's establisment, the organisation accomodated the diverse background of the members. Change to singular orientation only took place after the internal conflict in 2005 . 


\section{BIBLIOGRAPHY}

Akyol, Esra Demirci, the Role of Memory in the Historiography of Hatay: Strategies of Identity Formation through Memory and History, Germany: VDM Verlag Dr. Muller Aktiengesselshaft \& Co. KG and Licensors, 2009.

Al-Ittihaad, Special Edition, July 13, 1985; Nomor Khusus, July 13, 1985;

No. 10, May-June 1986; No. 19, March-April 1988; No. 25, JulyAugust 1989; July-August 1989; November-January 1993-1994; No. 44, December 1995; November 1996.

Amghar, Samir, "Salafism and Radicalization of European Muslims", in Samir Amghar (ed.), European Islam, Brussels: CEPS, 2007.

Amin, Muhammad, Kemampuan Anak-anak. Membaca al-Qur'an (Suatu Studi di Kabupaten Aceh Tenggara), Banda Aceh: Pusat Pengembangan Penelitian Ilmu-ilmu Sosial Universitas Syiah Kuala, 1993.

As-Sunnah 3, Year XI, 2007.

Azra, Azyumardi (et al.), Varieties of Religious Authority: Changes and Challenges in 20th Century Indonesian Islam, Singapore: ISEAS, 2010.

Baçi, Sefa, "Mixed-Marriage in the Netherlands," Master Thesis, Leiden University, 1999.

Balbaid, Aziz, Jadwal Dauroh Amsterdam, Amsterdam: PPME, December 11, 2009.

Bijvoegsel van de Nederlandse Staatscourant van 14 augustus 1974 156, 1, and cf.: Uittreksel uit het Verenigingenregister van de Kamer van Koophandel en Fabrieken voor 's-Gravenhage, V 410668, December 13, 1994.

Bruinessen, Martin van, Kitab Kuning: Pesantren dan Tarekat, transl. Farid Wajidi and Rika Iffati, Yogyakarta: Gading Pablishing, 2012.

Bulletin Afdeling Rotterdam 6, November 1999.

Dessing, Nathal M., Rituals of Births, Circumcision, Marriage, and Death among Muslims in the Netherlands, Leuven: Peeters, 2001.

Direktorat Pendidikan Agama Islam pada Masyarakat dan Pemberdayaan Masjid, Panduan Pesantren Kilat, Jakarta: Depag, 2004. 
Dirjen Bimbaga Kementrian Agama RI, Sejarah Pendidikan Islam di Indonesia, Jakarta: Depag, 1986.

Dirjen Bimbingan Masyarakat Islam dan Urusan Haji, Petunjuk Pelaksanaan Perkawinan di Luar Negeri, Jakarta: Depag RI, 1989.

Dirjen Kelembagaan Agama Islam, Panduan Penyelenggaraan Pesantren Kilat, Jakarta: Depag, 2005.

Ditpeka Pontren, Pola Penyelenggaraan Pesantren kilat (Studi Kasus Pondok Pesantren Babakan Ciwaringain, Cirebon, Jawa Barat), Jakarta: Depag, 2003.

Douwes, Dick (et al.), Nederlandse Moslims: van Migrant tot Burger, Amsterdam University Press: Salomé, 2005.

DPP PPME, Laporan DPP PPME pada Musyawarah Umum I dari Tanggal 25-26 Agustus 1973, The Hague: PPME, 1973.

DPP YMAE, Laporan Kerja 1976-1979, Achen, West Germany: YMAE, June 1, 1979.

Dzikir, Majlis, Mededeling, Amsterdam: PPME Amsterdam, November 3, 2005.

Eickelman, Dale F. and Jon W. Anderson, New Media in the Muslim World: the Emerging Public Sphere, 2nd ed., USA: Indiana University Press, 2003.

Euromuslem 8, May 1994; 16, January 1995; 22, July 1995; June 1997; May 1998; 55, April 1998; 67, July-August 1999; 74, September-October 2000; 82, January-February 2002; 91, July-August 2003; 447, Year 11, September 11, 2009; 460, Year 11, January 15, 2010; March 4, 2011; June 1, 2011; Ramadhan Edition, August 16, 2011; 515, Year 12, December 3, 2011.

Fathuri (et al.), Kiai, Musik dan Kitab Kuning, 1st ed., Depok: Desantara, 2009.

Al-Ghazāli, Abū Ḥamìd Muḥammad ibn Muḥammad, Al-Mustasfā min Tlm al-Usūil, 1st ed., Beirut: Dar al-Fikri, n.d.

Hassan, A., Soal-Djawab tentang Berbagai Masalah Agama, 2nd ed., Bandung: C. V. Dipenegoro, 1969.

Holden, Todd Joseph Miles and Scrase, Timothy J., Medi@sia: Global Medial tion in and out of Context, London and New York: Routledge, 2006. 
Sujadi

Humam, As'ad, Cara Cepat Belajar Membaca Al-Qur'an, Yogyakarta: Team Tadarus AMM, 1994.

ISIM Review 21: Migrants, Minoroties and the Mainstream, Spring 2008.

Iskandar, Hansyah (et al.), Handleiding Pengajian Remaja PPME, The Hague: PPME, 1998-1999.

Isyak, Mohammad, Laporan Pertanggung-Jawaban Pengurus PPME Wilayah Nederland Periode 1994-1996, The Hague: PPME the Netherlands, June 21, 1997.

Jawas, Yazid bin Abdul Qadir, Mulia dengan Manhaj Salaf, Bogor: Pustaka at-Taqwa, 2009.

Kasim, Azhari, Memorandum Akbir Jabatan Ketua Pengurus Sementara Masjid al-Hikmah, The Hague, PPME, July 31, 1997.

Krämer, Gudrum, and SabineSchmidtke (eds.), Speaking for Islam: Religious Authorities in Muslim Societies, Leiden-Boston: Brill, 2006.

Kurdi, Yani and DewiHendriks, Acara Rapat Evaluasi I Dep. Pendidikan dan Da'wah, The Hague: PPME, September 29, 1996.

Kurdi, Yani, Laporan Kerja Seksi Pendidikan dan Kaderisasi PPME Wilayah Nederland Periode 1992-1994, The Hague: PPME, Maret 28, 1994.

Landman, Nico, Van Mat Tot Minaret: de Institutionalisering van de Islam in Nederland, Amsterdam: VU Uitgeverij, 1992.

Laporan Kerja 1973-1976 PPME the Netherlands, The Hague: PPME, July 31, 1976.

Luth, Thohir, M. Natsir: Dakwah dan Pemikirannya, Jakarta: Gema Insani, 1999.

Machsun, T. Thoha, Laporan Pertanggung-Jawaban Program Kerja PPME Cabang Den Haag Periode 2000-2002, The Hague: PPME, September 1, 2002.

Maksum, A. Hambali, Laporan Umum Pengurus PPME Wilayah Nederland 1986-1988 pada Musyawarah PPME Wilayah Nederland ke-5, 26-27 November 1988, The Hague: PPME, November 27, 1988.

----, Laporan Umum Pengurus PPME Wil. Nederland 1984-1986 pada Musyawarah PPME Wil. Nederland 23-11-1986 di Den Haag, The Hague: PPME, November 23, 1986. 
Mas'udi, A. Firdaus, Laporan Kegiatan-kegiatan Kepengurusan Periode $1997-$ 1998, PPME The Hague, The Hague, 07 November 1998.

Maudoodi, Maulana Abul A'ala, The Laws of Marriage and Divorce in Islam (transl.), 3rd ed., Kuwait: Islamic Book Publishers, 2000.

Panji Masyarakat 568, March 1-10, 1988.

Poetra, Adjie Esa, Revolusi Nasyid, 1st ed., Bandung: MQS Publishing, 2004.

PPME Hoofdbestuur, Handleiding PR PPME, The Hague: PPME,19981999.

PPME Humas Section, Menuju Pemahaman Aqidah yang Benar, Amsterdam: PPME, December 6, 2009.

Qardawi, Yusuf, Figh al-Gina wal-Musiqi fi Daw'i al-Qur'an wa'-Sunna, Cairo: Maktaba wa Hiba, 2004.

Raboen, Sio (et al.), Het Jaar verslag van het Bestuur PPME Den Haag Periode 2002-2004, The Hague: PPME, April 3, 2005.

Ramadan, Tariq, Western Muslims and the Future of Islam, Oxford: University Press, 2004.

Rangkuti, Sjaiful, Laporan Pertanggung Jawab Mandataris: Musyawarah Umum PPME/Ketua Umum DPP PPME Periode 19879-1982, Achen: PPME, November 12-14, 1982.

Razaq, Husny Abdul (et al.), Programma PPME Jeugdkamp, Rotterdam: PPME, June 1996.

Razaq, Salah Salem Abdel, "Neo-Muslim Intellectuals in the West and Their Contributions to Islamic Thought and the Formation of Western Islam," Ph. D. Thesis, Leiden University, 2005.

Rolad, Anne Sofie, New Muslims in the European Context, Leiden-Boston: Brill, 2004.

Shadid, W. A. R. and Koningsveld, P. S. van, The Integration of Islam and Hinduism in Western Europe, Kampen: Kok Pharos Publishing House, 1991.

----, Moslims in Nederland, Alphen aan den Rijn: Samson Stafleu, 1990.

----, Islam in Dutch Society: Current Developments and Future Prospects, Kampen: Kok Pharos Publishing House, 1992. 
Soedarso, G. E. Rijono, Laporan Pertanggungjawaban Ketua PPME Cabang Den Haag Periode 1996-1997, The Hague: PPME, December 6, 1997. Speelman, Gé (eds.), Muslims and Christians in Europe Breaking New Ground, Kampen: Uitgeverij Kok, 1993.

Strijp, Ruud, “Om de Moskee,” Ph. D Thesis, Amsterdam University, 1998.

Sulchan, A. Naf'an, Laporan Pertanggungjawaban Program Kerja PPME/

YMAE Nederland Periode 1992-1994, The Hague: PPME, November 27, 1994.

----, Laporan Pertanggung-Jawaban Program Kerja PPME Wilayah Nederland Periode 1997-1999, The Hague: PPME, 1999.

----, Laporan Pertanggung-Jawaban Program Kerja PPME Wilayah Nederland Periode 1997-1999, The Hague: PPME, 2000.

Sulchan, Aaman, PPME Den Haag: Het Verslag 2005 en Vooruitzichtt 2006, The Hague: PPME, May 29, 2006.

Al-Syāfíī, Muḥammad ibn Idrīs, Al-Umm, 2nd ed., Beirut: Dār alFikr,1983.

Syamsuddin, Zaenal Abidin and Ainul Haris Arifin, Ulasan Tuntas tentang Tiga Prinsip Pokok: Siapa Rabbmu? Apa Agamamu? Siapa Nabimu?, Jakarta: Darul Haq, 1999.

Wehr, Hans, A Dictionary of Modern Written Arabic, ed. J. Milton Cowan, 3rd ed., Wiesbaden: Spoken Language Service Inc., 1976.

Yukleyen, Ahmet, "Localizing Islam in Europe: Religious Activism among Turkish Islamic Organizations in the Netherlands", in Muslim Minority Affairs 3, Vol. 29, September 2009.

Yunus, Mahmud, Metodik Khusus Bahasa Arab, Jakarta: P. T. Hida Karya Agung, 1983.

Zarkasyi, Dachlan Salim, Qiroati Metode Praktis Belajar Membaca al-Qur'an, Semarang: Roudlatul Mujawwidin, January 1990.

Zikra, May 1997.

\section{The Internet}

http://almuslimah.wordpress.com/2008/04/14/ikhtilath-dan- 
bahayanya/, accessed January 15, 2012.

http:/ / az-zair.blogspot.com/2010/09/kaedah-pengajaran-al-Qur'anmasa-kini.html, accessed June 26, 2011.

http://biografi.rumus.web.id/biografi-k-h-zainuddin-m-z/, accessed June 1, 2013.

http://www.iofc.nl/node/44122, accessed November 6, 2011.

http://majalah-assunnah.com/edisi/07xv/, accessed December 29, 2011.

http: / / mangunbudiyanto.wordpress.com/2010/07/26/ efektivitas-metode-iqro $\% \mathrm{E} \%$ \% $80 \% 99$-dalam-pembelajaranmembaca-al-qur\%E2\% $\% 0 \% 99$ an-di-tka-\%E2\%80\%93-tpa$\% \mathrm{E} 2 \% 80 \% 9 \mathrm{Camm} \% \mathrm{E} 2 \% 80 \% 9 \mathrm{D}-$ kotagede-yogyakarta/, accessed January 4, 20

http://rumaysho.com/about-me.html, accessed December 29, 2011.

http://www.pwi.or.id/index.php/presspediapwi/787-a-dari-ensiklopedipers-indonesia-epi, accessed June 1, 2013.

http://www.republika.co.id/berita/nasional/umum/11/07/05/lnueenzainuddin-mz-sejak-kecil-bakat-dakwahnya-sudah-terlihat, accessed December 29, 2011.

http:/ / www.youtube.com/watch?v=Zetx7VP3XUo\&feature=related, accessed November 7, 2011.

\section{Interview}

Astin (a Coordinator of Dawa Programme of PPME Amsterdam), December10, 2009.

Balbaid, A. Aziz (an Advisor of PPME Amsterdam), Amsterdam, July 28, 2008.

Balbaid, A. Aziz (an Advisor of PPME Amsterdam), Interview via e-mail, December 11, 2009.

Balbaid, A. Aziz (an Advisor of PPME Amsterdam), Interview, The Hague, April 7, 2011.

Hasyim, Nur (a Local Staff for Religious Affairs of Indonesian Embassy for the Netherlands), Mariahove, The Hague, December 5, 2008. 
Sujadi

Haedar, Abu, April 11, 2009.

Fatimah, Siti (a Chairperson of Educational Division of PPME Amsterdam), interview by phone, December 23, 2011.

Ishom, Asif (PPME's Knowledgable of Islam), The Hague, February 12, 2012.

Maasdam, Frans Maasdam (a Member of Dutch Speaking Group of PPME Amsterdam), Yogyakarta, August 23, 2011.

Muttaqin, Khoirul, Depok, West Java, March 9, 2010.

Ollong, Sufjan, Ridderkerk, May 5, 2009.

Sukirman, Remi (an Imam of Surinamese-Javanese Organization Called Rukun Islam [Islamic Pillar]), The Hague, February 6, 2011.

Sulchan, A. Naf'an (PPME's Knowledgeable of Islam), The Hague, December 11, 2011.

Sulchan, Ilman (One of PPME's Nasyid Remaja's Vocalists), The Hague, December 11, 2011. 